Original Paper $\quad$ http://ajol.info/index.php/ijbcs $\quad$ http://indexmedicus.afro.who.int

\title{
Species composition and diversity of freshwater snails and land snails at the swampy areas and streams edges in the urban zone of Douala, Cameroon
}

Edith Laure KENNE, Jeanne Agrippine YETCHOM-FONDJO, Mohamed Basile MOUMITE, Sedrick Junior TSEKANE, Babell NGAMALEU-SIEWE, Boris FOUELIFACK-NINTIDEM, Miric BIAWA-KAGMEGNI, Patrick Stève TUEKAM KOWA, Romaine Magloire FANTIO, Abdel Kayoum YOMON, Rossi Merlin KENTSOPTSAFONG, Armel Moise DIM-MBIANDA and Martin KENNE*

\author{
Zoology Unit, Laboratory of the Biology and Physiology of Animal Organisms, University of Douala, PO Box \\ 24157 Douala, Cameroon. \\ *Corresponding author; E-mail: medoum68@yahoo.fr; Tel. (+237) 677694731
}

\section{ACKNOWLEDGMENTS}

The Cameroonian Ministry of Higher Education provided funds through the research support program.

\begin{tabular}{lll}
\hline Received: 21-02-2021 & Accepted: 23-07-2021 & Published: 31-08-2021 \\
\hline
\end{tabular}

\begin{abstract}
Fascioliasis and bilharzia occur in the Littoral region of Cameroon. Recent reports indicate a high prevalence of bilharzia in school-age children in the locality of Njombé-Penja, close to the city of Douala. This infectious disease may spread in the near future to the city of Douala, especially if the localities at risk are visited by infected people, who defecate or urinate in streams or swamps as is the habit of populations in populous zones of the city and where environmental cleanliness is not respected. It is known that several molluscs are intermediate hosts of the infectious agents of this pathology but little is known about the snail's community structure at the coastal zone of the country. The present study aimed to establish a baseline of information on the distribution of snails in the urban environments of the Douala coastal Littoral-zone, as a first step in evaluating the status and the occurrence level of snails known as intermediate hosts of schistosomiasis and distomatosis agents. Seventy-three sample units where inspected from July to November 2020 in eight quarters of the Douala city, using 49 non-contiguous transects $5 \times 40 \mathrm{~m}^{2}$ each along streams and 24 noncontiguous quadrates $10 \times 10 \mathrm{~m}^{2}$ each around swamps. A total of 4,068 snail's shelter belonged to 9 families: 3 $(33.3 \%)$ and $6(66.7 \%)$ families for land and freshwater snails respectively. Specimens belonged to 14 genera [6 (42.9\%) and $8(57.1 \%)$ genera for land and freshwater snails respectively], and 30 species [14 (46.7\%) and $16(53.3 \%)$ species for land and freshwater snails respectively]. Land snails were most diverse $\left[\mathrm{E}\left(\mathrm{S}_{\mathrm{n}=151}\right)=14 \pm\right.$ 0 species] than freshwater snails $\left[\mathrm{E}\left(\mathrm{S}_{\mathrm{n}=151}\right)=11 \pm 1\right.$ species]. Economically important species were highly represented in land snails $(30.3 \%)$ and lowly represented in freshwater snails (6.1\%). Between land snails Achatina and Archachatina (invasive pests for agriculture) were highly recorded in Bépanda-Sic-Cacao, Makepé-Missoké and PK10-Plateau quarters while between freshwater snails known as obligate intermediate
\end{abstract}


hosts for fascioliasis and bilharzia agents, Lymnaea was recorded in Bépanda-Sic-Cacao, Nkomba and Mbanga-Pongo quarters while Biomphalaria occurred exclusively in PK10-Plateau quarter. The community exhibited low evenness, low species richness, low species diversity and low dominance by a few species. The theoretical lognormal model fitted the species abundance distributions and species exhibited a positive association (Schluter's ratio $\mathrm{VR}=6.69$, statistic $\mathrm{W}=53.49$, $\mathrm{df}=8, \mathrm{p}<0.001$ for land snails; $\mathrm{VR}=2.27, \mathrm{~W}=$ $18.18, \mathrm{df}=8, \mathrm{p}=0.020$ for freshwater snails; $\mathrm{VR}=4.17, \mathrm{~W}=33.42, \mathrm{p}<0.001$ for the pooled data). Low dominance by a few species indicated that study sites were slightly influenced by interspecific competition and/or disturbance by human activities.

(C) 2021 International Formulae Group. All rights reserved.

Keywords: Biodiversity, land snails, freshwater snails, urban area, Douala.

\section{INTRODUCTION}

Tropical ecosystems in general and the coastal region of Cameroon in particular, exhibit an impressive biological diversity, which testifies to the existence of numerous habitat opportunities and forms of inter- and intraspecific interactions. Among the living Invertebrates that inhabit the coastal ecosystem of Cameroon, the molluscs (Mollusca) are highly represented. Snails are exploited by humans for shellfish and flesh. Indeed, the shell is used for various ornaments, serves as source of calcium in the composition of poultry feed and the flesh is consumed by humans (Colley et al., 2014; Clavel, 2015; Adeyeye et al., 2020). In aquatic environments, freshwater snails are good bioindicators of chemical pollution because they can accumulate and concentrate in their bodies large amounts of toxic heavy metals (Bouthir et al., 2004). Otherwise, freshwater snails play the role of obligate intermediate hosts for infectious agents, among which the most frequently cited are cercariae of the digenetic trematodes worms (flukes) belonging to the genus Fasciala and Schistosoma, responsible for human and cattle chronic infection fascioliasis and schistosomiasis respectively (Ntonifor and Ajayi, 2007; Dawet et al., 2012; Adang et al., 2015). Among the snails mentioned there are freshwater species of the genera Biomphalaria, Bulinus, Oncomelania and Planorbarius whose presence in water points (streams, river edges and swamps) is a major risk factor for the spread of bilharzia (Dreyfuss and Rondelaud, 2011; Bridger et al., 2018; Chibwana et al., 2020). Several land snails are crop pests and cause damage in agriculture and horticulture. They feed on leaves, roots, tubers of vegetables as well as other crops and ornamental plants (Kant \& Diarra, 2016; Ismail et al., 2003; Heikal, 2015). Natural invasions by snails especially by obligate intermediate hosts of parasites would be a severe threat to human and cattle health. Natural invasions mostly occur in communities where certain conditions, either alone or in combination, provide a "niche opportunity". These conditions include the availability of resources, the absence of natural enemies, and the physical environment (Shea and Chesson, 2002). As snails occupy a central place in the functioning of swampy and streams ecosystems, invasions by obligate intermediate host species tend to have major ecological consequences (the flow of parasites and the snail's population would increase the infected human and cattle). Thanks to the large amount of the nesting resources the swampy environment provides, snails are the main component of the tropical marshy areas. In invaded areas, invader's success results from fewer attacks by enemies native to these areas, behavioural plasticity in their "buffet strategies", and, as a consequence, exotic 
pests reach densities that are much higher than normally occur in their native habitats (Shea and Chesson, 2002). This is the case of the Giant African land snails of the genera Achatina who was introduced in Brazil as a substitute for the European snail Helix aspersa maxima. However, its breeding was abandoned and the mollusc became an invasive species, found throughout Brazil and causing damage to health and the environment (Andreazzi et al., 2017; d'Ovidio et al., 2019). Several exotic snails have invaded many areas of the world, including both disturbed and undisturbed areas where they displace almost all the native species. This is the case of planorbid snails now commonly transported by man mainly through the aquatic plant trade and five of them (Biomphalaria glabrata, Bi. straminea, Bi. tenagophila, Bi. pfeifferi and Indoplanorbis exustus) can be considered as pests because of their role in the transmission of parasites to humans or domestic animals: the neotropical Bi. glabrata, Bi. straminea and Bi. tenagophila have proven their capacity to invade another continent sometimes creating new transmission foci while the African $B i$. pfeifferi and the Indian I. exustus have expanded their distribution area with longdistance dispersal (Pointier et al., 2005). In the Pacific Island, snails of the Euglandina rosea species complex and Platydemus manokwari flatworms were widely introduced in attempted biological control of giant African snail (Lissachatina fulica) but have been implicated in the mass extinction of the island snails (Gerlach et al., 2020). Available studies on schistosomiasis in humans and livestock are generally based on the presence/absence data of medically important snail species as a risk factor. In Gwong and Kabong localities of Nigeria the prevalence of the human schistosomiasis among residents was reported as highest among those that obtained water from rivers/stream than those who used well water, while there was no infection among those that obtained water from borehole (Dawet et al., 2012). But nothing was said about the presence of intermediate hosts. In savannah irrigated rice growing villages situated in Ivory Coast, the intensity of the infection of Schistosoma haematobium showed significant positive relations with the surface of rice cultivated in land valleys (Yapi et al., 2017). In Bauchi State (Nigeria) the occurrence of human schistosomiasis has been shown linked to the presence in the environment of five freshwater snail species of medical importance (Bulinus (Physopsis) globosus, Bu. (Bulinus) truncatus, Bu. (Bulinus) forskalii, Biomphalaria pfeifferi, and Lymnaea natalensis) and whose relative abundance varied according to the seasons of the year with a peak at the beginning of the dry season followed by a decline during the rainy season (Ntonifor and Ajayi, 2007). In Cameroon, schistosomiases due to $S$. haematobium and S. mansoni are frequently diagnosed in the population of Maga in the Far North of the country, with an overall prevalence of $30 \%$, making Maga a mesoendemic area (Saotoing et al., 2016). In the Littoral zone of Njombe-Penja, the overall prevalence of schistosomiases $(31.9 \%)$ due to S. guineensis, S. haematobium and S. mansoni were recorded, and the prevalence of this disease was significantly higher in younger women and among residents (Tonga et al., 2019). In the same locality, the prevalence of schistosomiasis and distomatosis has seen a considerable drop in recent years due to the effectiveness of the bi-annual dewoming campaign organized by the Public Health Authorities. But several infected persons are still recorded especially in children of school age. Indeed, according to the investigations of Nzenou et al. (2020) carried out in NjombéPenja which is a locality very close to the city of Douala, the overall prevalence of 
schistosomiasis was $9.7 \%$, with $7.8 \%$ and $1.9 \%$ of school children infected with $S$. mansoni and $S$. haematobium, respectively and $0.7 \%$ co-infection with both species. The intensities of S. haematobium and S. mansoni infection were 2.1 eggs per $10 \mathrm{~mL}$ of urine, 94 eggs per gram of stool respectively. A significant association was found between schistosomiasis and playing in the stream and the presence of the river and back water in the vicinity of schools. This pathology could extend to the city of Douala if environmental hygiene control measures are not taken in the localities of the city with a high risk of production of the infectious agent. Yet the checklist, abundance data and dominance status in the snail community are essential for the establishment of an effective vector control program. The present study aimed to establish a baseline of information on the distribution of snails in the urban environments of the Douala coastal Littoralzone, as a first step in evaluating the status and the occurrence level of snails known as intermediate hosts of schistosomiasis and distomatosis agents.

\section{MATERIALS AND METHODS}

\section{Study area}

Studies were carried out from July to November 2020 in the urban areas of Douala (Littoral-zone of Cameroon; $4^{\circ} 3^{\prime} \mathrm{N}, 9^{\circ} 41^{\prime} \mathrm{E}$ ) (Figure 1A,B). On the base of the presence of a stream and/or a swamp, eight quarters were selected in three districts: (1) Douala III $\left(4^{\circ} 2^{\prime} 36^{\prime \prime} \mathrm{N}, \quad 9^{\circ} 44^{\prime} 33^{\prime \prime} \mathrm{E}\right), \quad$ (2) Douala IV $\left(4^{\circ} 4^{\prime} 44^{\prime \prime} \mathrm{N}, 9^{\circ} 40^{\prime} 00^{\prime \prime} \mathrm{E}\right)$ and (5) Douala V $\left(4^{\circ} 5^{\prime} 47^{\prime \prime} \mathrm{N}, 9^{\circ} 45^{\prime} 6^{\prime \prime} \mathrm{E}\right)$. A total of 32 sampling sites were randomly selected in eight quarters (Figure 1C). We carried out a total of 59 sampling units divided into 35 transects of $10 \times 20 \mathrm{~m}$ each delimited on both banks of the streams, and 24 quadrats of $10 \times 10 \mathrm{~m}$ each delimited on the perimeter of the swamps, from the center of each swamp to the mainland. The transects were used along the main channel of the streams that crossed each of five quarters (Bépanda-Sic-Cacao, CitéBerge, PK10-Plateau, Maképé-Missoké and Ndogbong). The quadrats were used around swamps in each of three quarters (Nkomba, Mambanda and Mbanga-Pongo).

In Douala III, snails were sampled in three quarters (Figure 1C): (1) in "Cité-Berge", 10 transects were randomly delimited and inspected during five days, at four sampling sites (Site 1: $4^{\circ} 00^{\prime} 8.26^{\prime \prime} \mathrm{N}, 9^{\circ} 45^{\prime} 00.60^{\prime} \mathrm{E}$; Site 2: $\quad 3^{\circ} 59^{\prime} 54.21^{\prime \prime} \mathrm{N}, \quad 9^{\circ} 45^{\prime} 20.9^{\prime \prime} \mathrm{E} ;$ Site 3: $3^{\circ} 59^{\prime} 25.63^{\prime \prime} \mathrm{N}, 9^{\circ} 45^{\prime} 12.96$ ' $\mathrm{E}$ and Site 4: 3 ${ }^{\circ} 9^{\prime} 25.63$ 'N, 945'12.90”'E; Figure 1D), (2) in the populous "Mbanga-Pongo" quarter located in the swampy mangrove along the Atlantic coast, eight quadrats where inspected during three days at four sampling sites (Site 1: 3 $59^{\circ} 00.95^{\prime}$ 'N, 9०45'54.16”'E; Site 2: 3०58'51.88’N, 9०45'17.30’'E; Site 3: $3^{\circ} 58^{\prime} 49.48^{\prime \prime} \mathrm{N}, 9^{\circ} 44^{\prime} 57.36^{\prime \prime} \mathrm{E}$ and Site 4: $3^{\circ} 58^{\prime} 38.07^{\prime}$ N, $9^{\circ} 45^{\prime} 35.62$ 'E; Figure 1D), and (3) in "PK10-Plateau" quarter characterized by high insalubrities and located far from the Atlantic coast and the Wouri river, four transects were inspected during five days at four sampling sites on each stream edge (Site 1: $4^{\circ} 2{ }^{\prime} 32.22^{\prime \prime} \mathrm{N}, \quad 9^{\circ} 46^{\prime} 10.26^{\prime \prime} \mathrm{E} ;$ Site 2: 4²'42.69'”N, 9॰46'33.77'”; Site 3: $4^{\circ} 2^{\prime} 39.99^{\prime \prime} \mathrm{N}, \quad 9^{\circ} 45^{\prime} 52.74$ ' $\mathrm{E}$ and Site 4: 4²’22.44”N, 9॰46’31.58”'E; Figure 1E).

In Douala IV located in Bonabéri, snails were sampled in two quarters (Figure 1F): (1) in the swampy area "Nkomba", eight quadrats were inspected during three days in four sampling sites (Site 1: $4^{\circ} 4^{\prime} 8.46^{\prime \prime} \mathrm{N}$, $9^{\circ} 39^{\prime} 46.69^{\prime \prime} \mathrm{E} ; \quad$ Site $\quad 2: \quad 4^{\circ} 3^{\prime} 46.97^{\prime} \mathrm{N}$, $9^{\circ} 39^{\prime} 38.12^{\prime \prime} \mathrm{E} ; \quad$ Site $3: \quad 4^{\circ} 3^{\prime} 41.5^{\prime \prime} \mathrm{N}$, $9^{\circ} 39^{\prime} 21.54^{\prime \prime} \mathrm{E}$ and Site 4: 4³'35.78”N, 9³9'32.73"E, (2) in "Mambanda" quarter, eight quadrats were inspected during three days in four sampling sites (Site 1: 


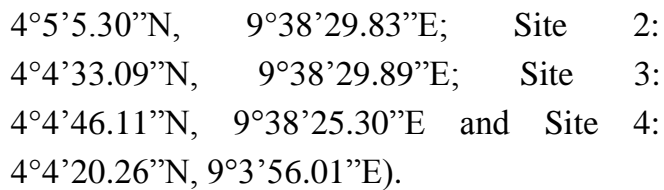

In Douala V, snails were sampled in three quarters: (1) in "Bépanda-Sic-Cacao" which is a populous quarter where wastewater (from brewing factories and neighbouring homes) is frequently discharged in the stream, five transects were inspected at each stream edge during four days at four sampling sites (Site 1: 4³'20.15' N, 9०43'39.57'E; Site 2: 4³'10.06”'N, 943'40.31'E; Site 3: $4^{\circ} 3^{\prime} 4.35^{\prime \prime} \mathrm{N}, \quad 9^{\circ} 43^{\prime} 32.57^{\prime \prime} \mathrm{E}$ and Site 4: $4^{\circ} 3$ '36.81'N, 9०43'46.17'”E; Figure 1G), (2) in the swampy populous residential quarter "Maképé-Missoké", 11 transects at one stream edge where inspected during four days at four sampling sites (Site 1: $4^{\circ} 4^{\prime} 3.50^{\prime \prime} \mathrm{N}$, 9०44'48.58'"E; $\quad$ Site $\quad 2: \quad 4^{\circ} 4^{\prime} 7.59^{\prime \prime} \mathrm{N}$, 9०44'40.48”'E; Site 3: $4^{\circ} 4^{\prime} 12.80^{\prime \prime} \mathrm{N}$, $9^{\circ} 44^{\prime} 32.60^{\prime \prime} \mathrm{E}$ and Site 4: $4^{\circ} 4^{\prime} 7.46^{\prime \prime} \mathrm{N}$, $9^{\circ} 44^{\prime} 8.23$ "E; Figure 1G), and (3) in "Ndogbong" quarter, five transects were selected at the stream edges and inspected during four days in four sampling sites (Site 1: 4²'56.46”N, 944'40.08'"E; Site 2: 4³'6.93”N, 9०44'41.36”'E; Site 3: $4^{\circ} 3^{\prime} 14.18^{\prime \prime} \mathrm{N}, 9^{\circ} 44^{\prime} 30.89^{\prime \prime} \mathrm{E}$ and Site 4: $4^{\circ} 3$ '33.27’N, 9॰44’31.53'”E; Figure 1H).

Water points represent favourable environments for the development of intermediate hosts of the schistosomiasis and distomatosis agents. Douala and the suburbs of the city are $17 \mathrm{~m}$ above sea level and the prevailing climate is tropical and is "Am" according to Köppen and Geiger classification (Kottek et al., 2006). The climate is characterized by significant rainfall most months, with a short dry season. The driest month is December, with $39 \mathrm{~mm}$ of rains. In August, the precipitation reaches its peak, with an average of $681 \mathrm{~mm}$. The average temperature in Douala and the suburbs is
$26.2{ }^{\circ} \mathrm{C}$ and the average annual precipitation reaches $3,702 \mathrm{~mm}$. Between the driest and wettest months, the precipitation amplitude is $642 \mathrm{~mm}$. A variation of $3.0^{\circ} \mathrm{C}$ is recorded over the year (Climate-data.org, 2021).

\section{Sampling design}

Along the two banks of each stream, live snail shells were collected by randomly selecting 49 non-contiguous $5 \times 40 \mathrm{~m}$ transects from the centre of the stream to the mainland. Streams were recorded in four localities (Bepanda-Sic-Cacao, Cité-Berge, MaképéMissoké and Ndogbong). As for the marshy points, we randomly delimited 24 noncontiguous quadrats of $10 \times 10 \mathrm{~m}$ positioned on the perimeter of the marsh from the water to the mainland. Swampy points were located in five quarters (Nkomba, Mambanda, MaképéMissoké, Mbanga-Pongo and PK10-Plateau). A total of 73 sample units were used to collect during 32 days (three to five days per locality) freshwater snails and land snails. In each transect or quadrat, three people excavated the mud, inspected the aquatic plants and on dry land the litter and soil were removed at $20 \mathrm{~cm}$ deep, the stones were turned over and the plants were carefully checked for one day (between 10 a.m. and 2 p.m.), and the shells of living pulmonary gastropods were collected and then stored in labelled 20-liter plastic basins, each with a lid and containing $70^{\circ}$ alcohol. The capture technique is manual, the shells being detected with the naked eye. The work was carried out only once in each sampling site. The collected shells were taken to the laboratory of Biology of Animal Organisms of the Faculty of Sciences (University of Douala) where they were sorted into morpho-species, based on the shell morphology criteria. They were compared to the laboratory's reference collection and identifications were confirmed using taxonomic keys (Mouthon, 1982; Daget, 2003; 
Vrignaud, 2011; Memel et al., 2017), illustrated catalogues of Cucherat and Demuynck (2006) and Clavel (2015) and consulting mollusc databases available online (Galli, 2013; MolluscaBase, 2021). In order to consider recent developments in the taxonomy of snails, we consulted annotated check lists of Welter-Schultes et al. (2011). Specimens were stored in the laboratory of Biology and Physiology of Animal Organisms, Faculty of Science of the University of Douala.

\section{Data analysis}

A data matrix of abundance counts of species from each locality was constructed. For each species, the mean value and the variance of abundance count were determined from the pooled data. The number of species per family was determined and the percentage calculated from the total number. Comparisons of raw occurrence of snail species per family were set up using the Fisher-Freeman-Halton exact-test from StatXact software 3.1®. Between quarters simultaneous comparison was set up using the one-way ANOVA test from SigmaStat software $2.0 \AA$ and the post-hoc comparisons were set up when relevant using the StudentNewman-Keul procedure. Comparisons of proportions were conducted using the Fisher exact test. Indexes were determined using PAST 3.05 software (Hammer et al., 2001). We determined the abundance of the $i^{\text {th }}$ species $n_{i}$, the sample size $n=\sum n_{i}$, the observed total number of species $\mathrm{S}$, the Shannon-Weaver diversity index H', the Simpson diversity index D, the Margalef index $\mathrm{Mg}$, the community evenness indexes and the Hill diversity numbers (Kikvidze and Ohsawa, 2002; Chen, 2004). The richness ratio $d=S / n$ was determined to confirm species richness (value close to 0 suggests low species richness of the community). The theoretical species richness $\mathrm{T}$ was determined using the abundance based non-parametric estimators Chao 1 and the sampling success was estimated using the formula $(\mathrm{S} / \mathrm{T}) \times 100$. The degree of dominance of a few species was evaluated using the Berger-Parker dominance index $\mathrm{I}_{\mathrm{BP}}=\mathrm{n}_{\max } / \mathrm{n}$ (value close to 0 suggests all taxa are equally present while value close to 1 suggests that one or a few taxa dominate the community) (Cheng, 2004). The overall species covariance was evaluated using the presence/absence data. Between species, correlations were determined using the Kendall's Tau correlation. The rank abundance plotting was used to illustrate the degree of species abundance in each locality. The species abundance distribution curves were set up using Whittaker plots, by ranking species (from most to less abundant) in the $\mathrm{x}$ axis and their relative frequency in the $y$-axis. In each situation, the goodness of fit of the observed abundance distribution to a theoretical model was first assessed by calculating the Pearson correlation between the logarithms of the numbers and the ranks of the snail species and interpreted as follows: (1) $\mathrm{r}<-0.95$ reflected an adjustment of poor quality; (2) $\mathrm{r} \approx-0.95$ reflected an approximate fit; (3) $r \approx-0.98$ indicated a satisfactory fit; and (4) $r \geq-0.99$ reflected an excellent fit. The package vegan of $\mathrm{R}$ 3.4.1. software (R-Core Team, 2018) helped us to establish the species abundance distribution model of the communities. For the present study, we used five theoretical models: broken stick, Motomura geometric series, Preston's lognormal, Zipf and Zipf-Mandelbrot model. The best fitted theoretical model was selected using the Akaike Information Criteria (AIC) procedure (Johnson and Omland, 2004). Therefore we determined the parameters on which the selected theoretical model depended. 

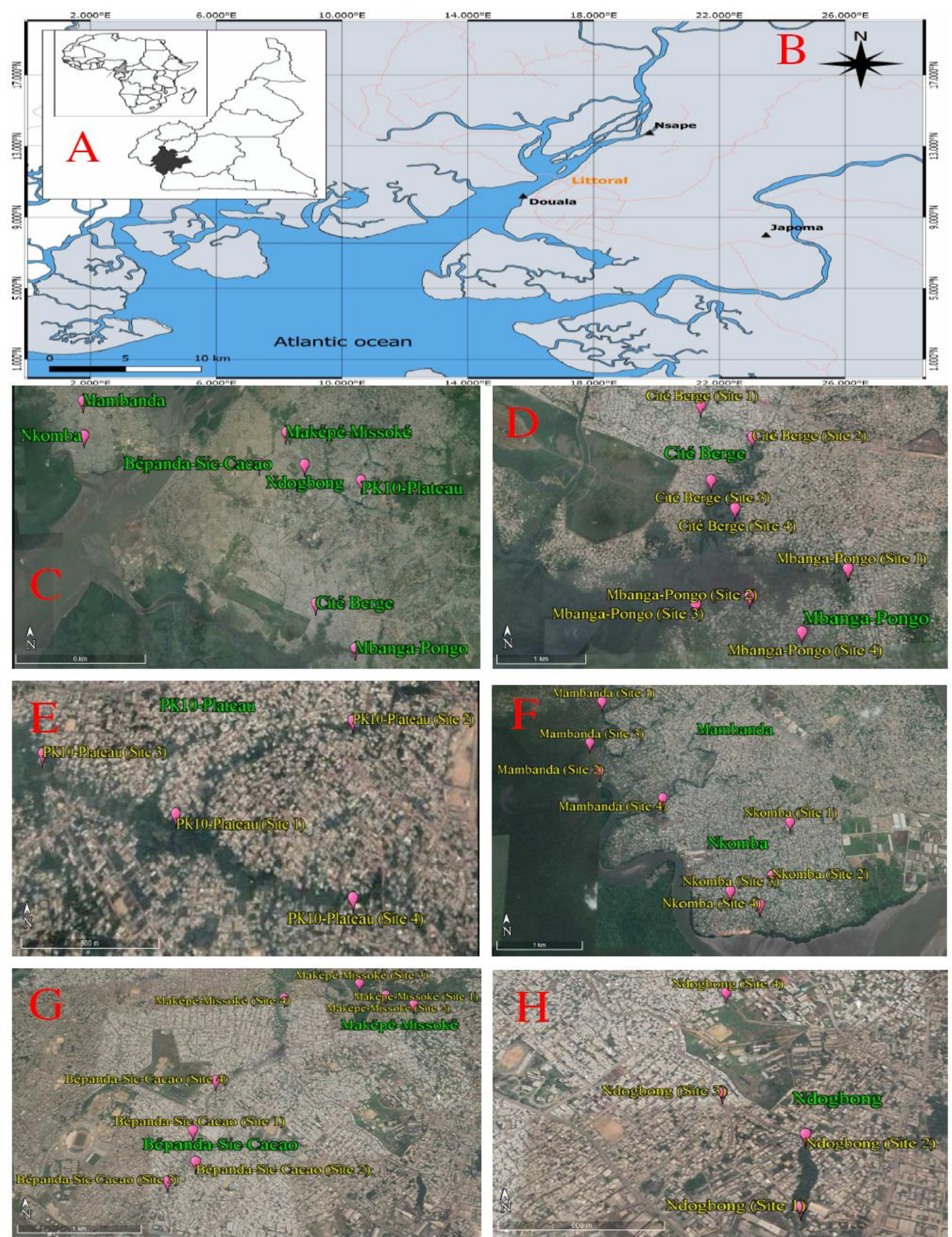

Figure 1: Location of the sampling sites.

$\mathrm{A}=$ location of the Littoral region in Cameroon; B = location of Douala city in the Littoral region of Cameroon; $\mathrm{C}=$ location of the eight study quarters in Douala urban zone; $\mathrm{D}=$ location of the four sampling sites respectively in "Cité Berge" and "Banga-Pongo; $\mathrm{E}=$ location of the four sampling sites in "PK10-Plateau"; $\mathrm{F}=$ location of the four sampling sites respectively in "Mambanda" and "Nkomba"; $\mathrm{G}$ = location of the four sampling sites respectively in "Bépanda-Sic-Cacao" and "MaképéMissoké"; $\mathrm{H}=$ location of the four sampling sites in "Ndogbong". 


\section{RESULTS}

\section{Inventory of snail species}

Captured specimens belonged to nine families (Achatinidae, Ferussaciidae, Lymnaeidae, Neridae, Physidae, Planorbidae, Sphaeriidae, Succineidae and Thiaridae) divided into three land snail families and six freshwater and brackish water snails. Land snails were recorded in five quarters [Achatinidae in four quarters (Bépanda-SicCacao, Mambanda, Maképé-Missoké and PK10-Plateau), Ferussaciidae in two quarters (Maképé-Missoké and Pk10-Plateau) and Succineidae in three quarters (Bépanda-SicCacao, Nkomba and Maképé-Missoké)]. Among the land snails, Succineidae were mostly represented $(2.1 \%)$ followed by Achatinidae (1.8\%) and lastly Ferussaciidae were the less represented $(0.2 \%)$ (Table $1 \mathrm{~A})$. Freshwater and brackish water snails were recorded in all localities [Lymnaeidae in three quarters (Bépanda-Sic-Cacao, Nkomba and Ndogbong), Neridae in three quarters (CitéBerge, Nkomba and Mbanga-Pongo), Physidae in four quarters (Bépanda-Sic-Cacao, Nkomba, Maképé-Missoké and Ndobong), Planorbidae in one quarter (Pk10-Plateau), Sphaeriidae in one locality (Mbanga-Pongo), and Thiaridae in five quarters (Bépanda-SicCacao, Cité-Berge, Nkomba, Mambanda and Mbanga-Pongo)]. Among these aquatic snails Thiaridae were mostly represented $(72.4 \%)$ followed by Physidae (13.5\%), Lymnaeidae (6.2\%), Neridae (3.3\%) while Planorbidae and Sphaeriidae were rarely recorded $(0.2 \%$ and $0.5 \%$ respectively, Table $1 \mathrm{~B})$. No family was collected simultaneously in all localities. In terms of abundance, freshwater and brackish water families were more represented than land snails $(95.9 \%$ and $4.1 \%$ respectively, Fisher exact-test: $\mathrm{p}<0.001$ ).

Collected specimens belonged to 30 species. The difference between the number of land snail species (14 species) and that of aquatic snail species (16 species) was not significant $(46.7 \%$ and $53.3 \%$ respectively; Fisher exact-test: $\mathrm{p}=0.797)$. Among the land snails the species richness was significantly high in Achatinidae (78.6\%) than in Ferussaciidae and Succineidae $(7.1 \%$ and $14.3 \%$ respectively; Fisher-Freeman-Halton statistic $=6.888 ; \mathrm{df}=2 ; \mathrm{p}=0.038 ;$ Table 2A). Among the aquatic families the distribution of the 16 species was not statistically different (Thiaridae: 43.8\%; Lymnaeidae: $12.5 \%$; Neridae: $25.0 \%$; $6.3 \%$ for Physidae, Planorbidae and Sphaeriidae respectively; Fisher-Fredman-Halton statistic $=6.373 ; \mathrm{df}=$ $5 ; \mathrm{p}=0.290$ ) (Table 2B). According to the overall analysis the number of snail species was significantly high along the streams situated at Bépanda-Sic-Cacao (12 species: nine land species and three aquatic species) and Maképé-Missoké (11 species: 10 land species and one aquatic species) than that recorded in the six other sites : Cité-Berge: three aquatic species; Nkomba: nine species (one land species and eight aquatic species); Mambanda: seven species (one land species and six aquatic species); Mbanga-Pongo: seven aquatic species; Ndogbong: three aquatic species; and PK10-Plateau: seven species (six land species and one aquatic species).

\section{Snail's species abundance}

A total of 4,068 specimens (mean \pm standard error: $136 \pm 76$ specimens; 30 species) was collected in the eight urban quarters. Among these individuals, 165 specimens (12 \pm 4 specimens; 14 species) were land snails, and 3,903 specimens (244 \pm 138 specimens; 16 species) were aquatic species (Tables 3). The mean difference was not statistically significant (Student $\mathrm{t}$-test: $\mathrm{t}=$ $1.577 ; \mathrm{df}=28 ; \mathrm{p}=0.126$ ). Between the eight quarters, abundances varied with no significant difference (One-Way ANOVA: $\left.\mathrm{F}_{(7 ; 232)}=0.751 ; \mathrm{p}=0.629\right)$.

Between the 14 land snails two Achatinidae [Achatina fulica (Ferussac, 1821) and Ac. isotoma (Pfeiffer, 1854)] were recorded exclusively in Maképé-Missoké quarter while two other Achatinidae 
[Archachatina marginata var. clenchi Bequaert, 1950 and Ar. marginata var. suturalis (Philippes, 1849)] were recorded exclusively in Bépanda-Sic-Cacao quarter and Achatina vignoniana Morelet, 1874 was recorded exclusively in PK10-Plateau quarter. The Succineidae Succinea pascali Baudon, 1879 was recorded exclusively in BépandaSic-Cacao quarter. The eight remaining species were recorded simultaneously in two or three quarters (Table 3A).

Between the 16 aquatic snails two Neridae (Neritina glabrata Sowerby II, 1849 and Ne. adansoniana Recluz, 1841) and the Sphaeriidae (Pisidium subtruncatum Malm, 1855) were recorded exclusively in MbangaPongo quarter. Two Thiaridae [Melanoides angolensis Mandahl-Barthm, 1974 and Pachymelania aurita (Muller, 1774)] were recorded exclusively in Mambanda quarter. Finally, the Planorbidae [Biomphalaria pfeifferi (Krauss, 1848)] was recorded exclusively in PK10-Plateau quarter. The 10 remaining species were recorded simultaneously in two or three quarters (Table 3B).

On the base of the species abundances, the snail community in Bépanda-Sic-Cacao was highly represented by the Physidae freshwater Physella (Physa) acuta (Draparnaud, 1805) (Figure 2A) while in CitéBerge, Nkomba and Mambanda quarters, the community was highly represented by the Thiaridae Melanoides anomala (Dautzenberg \& Germain, 1914) (Figure 2B-D). The Succineidae $S$. pascali was highly abundant in Maképé-Missoké quarter (Figure 2E) while the Thiaridae Melanoides kinshasaensis Dupuis \& Putzeys, 1900 was highly abundant in Banga-Pongo quarter (Figure 2F). At Ndogbong quarter the Physidae Ph. acuta and the Lymnaeidae Lymnaea (Galba) truncatula (Muller, 1774) were highly represented (Figure 2G) while in PK10-Plateau quarter the Planorbidae Bi. pfeifferi and the Ferussaciidae Caecilioides acicula (Muller, 1774) were mostly represented (Figure 2H). The
Succineidae Succinea pascali was the highly recorded land snail (Figure 3A), the Planorbidae Bi. pfeifferi was the highly recorded freshwater snail (Figure 3B) and on the base of the overall data the Thiaridae $M$. anomala was highly represented than other species (Figure 3C).

\section{Snail's community structure}

Margalef indexes showed high snailspecies richness in four localities: BépandaSic-Cacao (12 species; Margalef index: $\mathrm{Mg}=$ 1.923), Maképé-Missoké (11 species; $\mathrm{Mg}=$ 2.206), Nkomba (nine species; $\mathrm{Mg}=1.419$ ) and PK10-Plateau (7 species; $\mathrm{Mg}=1.914)$. The very low value of Margalef index was observed in the four other localities $(\mathrm{Mg}<1.0)$ (Table 4A). On the base of the Margalef index the richness was high in the land snails (14 species; $\mathrm{Mg}=2.546)$ and low in the freshwater snails (16 species; $\mathrm{Mg}=1.814$ ) (Table 5A). In all cases, the species richness is statistically low (richness ratio was closed to 0 ) (Table 4A and 5A).

Considering the Chao1 non-parametric estimator, the sampling success showed a very high score $(100.0 \%)$ in four quarters (CitéBerge, Maképé-Missoké, Mbanga-Pongo and Ndogbong) and in freshwater snails. Moderately high scores $(85.7 \%, 87.5 \%$, $96.0 \%, 96.8 \%$ and $97.7 \%$ ) were recorded respectively in four quarters (Nkomba, Mambanda, PK10-Plateau and Bépanda-SicCacao), in the overall data and in the land snail community (Table 4A and 5A).

The higher species diversity was recorded in Cité-Berge and in land snails (indexes closed to the maximum value) and lower in the seven other localities and in freshwater snails (indexes <0.5) (Table 4B and 5B). Communities observed in five quarters (Mambanda, Maképé-Missoké, Mbanga-Pongo, Ndogbong and PK10-Plateau) and in land snails, were highly even (Pielou's index $\mathrm{J}>0.5$ ) while it was the contrary for three other quarters, for the overall data and 
for the freshwater snails $(\mathrm{J} \leq 0.5)$ (Table $4 \mathrm{C}$ and $5 \mathrm{C})$.

A very high dominance by a few species was noted in three quarters (BépandaSic-Cacao, Cité-Berge and Mambanda), in overall data and in freshwater snail's community (Berger-Parker's index $\mathrm{I}_{\mathrm{BP}}>0.5$ ) while it was the contrary in the five other localities and in the land snail's community $\left(\mathrm{I}_{\mathrm{BP}} \leq 0.5\right) \quad$ (Table 4D and 5D). The rankabundance plotting of the species abundance distributions of the land snails and freshwater snails presented a concave appearance suggesting the presence of co-dominants (Figure 2 and 3). According to the Hill number 2 index, two species [Ph. acuta and $S$. putris] co-dominated the snail community in Bépanda-Sic-Cacao. M. anomala was the only dominant species in Cité-Berge while four species [M. anomala, Pa. fusca var. mutans, $P h$. acuta and Ly. truncatula] co-dominated the snail community in Nkomba quarter. Three Thiaridae [M. anomala, Pa. fusca var. fusca and Pa. fusca var. mutans] codominated the snail community in Mambanda. Three other species [S. pascali, Ph. acuta and Ac. iredalei] co-dominated the snail community in Maképé-Missoké. Three species [M. kinshasaensis, Pa. fusca var. mutans and $N$. glabrata] were co-dominants in Mbanga-Pongo. The Physidae Ph. acuta and the Lymnaeidae Ly. truncatula co-dominated the snail community in Ndogbong. Five species [B. pfeifferi, C. acicula, Ac. iredalei, Limicolaria cailliauidi (Pfeiffer, 1850) and Ac. raffrayi Jousseaume, 1883] were codominants in PK10-Plateau quarter.

The land snail community was codominated by six species (Ac. achatina (Linnaeus, 1758) Ac. iredalei Preston, 1910, Lissachatina immaculata (Lamarck, 1822), S. pascali, S. putris (Linnaeus, 1758), and Li. cailliauidi) (Table 4; Figure 3A) while the freshwater snail community was codominated by 3 species (B. pfeifferi, Li. cailliauidi and Ar. marginata var. clenchi) (Table 4; Figure 3B) and finally the overall data showed co-domination by four species (M. anomala, Ph. acuta, M. kinshasaensis and Pachymelania fusca var. mutans) (Table 4; Figure 3C) corresponding respectively to $80.6 \%, 79.5 \%$ and $83.5 \%$ of the total collection.

The individual rarefaction curves plotted for the land snails and the freshwater snails communities approached species saturation plateaus with similar slopes. The curve observed in the freshwater snail's community was situated faraway below that of the land snail's community, suggesting the lowest species richness at the freshwater snail's community and the highest species richness at the land snail's community (Figure 4). Then for a standard sample of 151 individuals, the settlement in the land snail's community appeared most diverse $\left[\mathrm{E}\left(\mathrm{S}_{\mathrm{n}=151}\right)=\right.$ $14 \pm 0$ species], followed by the freshwater snail's community $\left[\mathrm{E}\left(\mathrm{S}_{\mathrm{n}=151}\right)=11 \pm 1\right.$ species $]$.

\section{Snail's community structure model}

Adjustment of abundance distributions to the five commonly known theoretical models showed that the fit was of satisfactory quality in land snail's community (Pearson correlation: $\quad \mathrm{r}=-0.976 ; \mathrm{p}<0.001)$, of approximate quality in freshwater snail community and in the overall data $(r=-0.966$; $\mathrm{p}<0.001$ and $\mathrm{r}=-0.964 ; \mathrm{p}<0.001$ respectively). On the base of the AIC values (Table 6) and the species abundance distributions (Figure 4), the Preston's lognormal model fitted the community structure of the land snails (mean value $\bar{x}=0.758$, variance statistic $\sigma^{2}=0.318$, chi-square goodness of fit $\chi^{2}=5.1, \mathrm{p}=0.024$, Preston's environmental constant $\mathrm{m}^{\prime}=0.142$ ). The same trend was observed in the case of the freshwater snails $\left(\bar{x}=1.625, \sigma^{2}=0.794\right.$, $\left.\chi^{2}=5.097, \mathrm{p}=0.024, \mathrm{~m}^{\prime}=0.134\right)$. The numbers of octaves $\mathrm{R}$ was 7,11 and 7 respectively. The number of species in the modal octave $S_{0}$ was $5, \quad 4.5$ and 7.5 respectively. The number of species in the octave most distant from the modal $\mathrm{S}\left(\mathrm{R}_{\max }\right)$ was two, one and one respectively. The 
lognormal parameter "a" was $0.239,0.175$ and 0.203 respectively. These statistics allowed the following lognormal regressions: $S\left(R_{i}\right)=$ $5 \mathrm{e}^{\left(-0.2392 \mathrm{Ri}^{2}\right)}$ with $-4 \leq \mathrm{R}_{\mathrm{i}} \leq+2$ for the land snails and $\mathrm{S}\left(\mathrm{R}_{\mathrm{i}}\right)=4.5 \mathrm{e}^{\left(-0.175^{2} \mathrm{R} \mathrm{i}^{2}\right)}$ with $-5 \leq \mathrm{R}_{\mathrm{i}} \leq+7$ for the freshwater snails. It was the contrary for the overall pooled data (lognormal model test $\bar{x}=1.140, \sigma^{2}=0.878, \chi^{2}=6.428, \mathrm{p}=0.377$ ). The whole species abundance distribution fitted the fisher's log-series model $\left(\chi^{2}=\right.$ $12.930, \mathrm{p}<0.001,4,068$ individuals, 30 species, Fisher's index of diversity $\alpha=4.391 \pm 0.299$, model's parameter $x=0.999$ ) and the Fisher's $\log$-series regression was $\mathrm{S}_{\mathrm{i}}=4.391\left(\mathrm{x}^{\mathrm{i}} / \mathrm{i}\right)$ where $S_{i}$ was the number of species represented by "i" individuals.

\section{Interspecies association and correlations}

Based on the sample units from all the eight study localities the species exhibited a positive association in presence/absence data (Schluter's variance ratio VR $=6.69, \mathrm{~W}$ statistic: 53.49 , df $=8, p<0.001$ for land snail's community; $\mathrm{VR}=2.27, \mathrm{~W}=18.18, \mathrm{df}$ $=8, \mathrm{p}=0.020$ for freshwater snails; $\mathrm{VR}=$ $4.17, \mathrm{~W}=33.42, \mathrm{p}<0.001$ for the whole community).

Between Achatinidae land snails, Achatina achatina was positively correlated with seven species (Ac. iredalei, Archachatina marginata var. eduardi Pilsbry, 1909, Ar. marginata var. clenchi, Ar. marginata var. saturalis, Limnicolaria cailliauidi and Lissachatina immaculata). Ac. iredalei was positively correlated with seven species (Ac. fulica, Ac. isotoma, Ac. raffrayi, Caecilioides acicula, Li. cailliauidi, Ls. immaculate and Succinea pascali). Ac. fulica was positively correlated with $S$. pascali while Ac. isotoma was positively correlated with two species (Ac. fulica and $S$. pascali). Ac. rafffrayi was positively correlated with three species (Archachatina marginata var. clenchi, Ar. marginata var. suturalis and C. acicula). Ac. vignoniana was positively correlated with $C$. acicula while Ar. marginata var. eduardi was positively correlated with two species ( $A r$. marginata var. clenchi and Ar. marginata var. saturalis). Ar. marginata var. clenchi was positively correlated with two species ( $A r$. marginata var. suturalis and the Succinidae $S$. putris). Ar. marginata var. saturalis was positively correlated with $S$. putris. Li. cailliauidi was positively correlated with five species (Ac. isotoma, Ac. fulica, Ac. raffrayi, $C$. acicula and $S$. pascali). Finally, Ls. immaculata was positively correlated with five species (Ac. raffrayi, Ar. marginata var. eduardi, Ar. marginata var. clenchi, Ar. marginata var. suturalis and Li. cailliauidi) (Table 7A). Other correlations were not significant.

Between freshwater snails, the Lymnaeidae Lymnaea (Radix) natalensis Krauss, 1,848 was positively correlated with Ly. (Galba) truncatula and Physella (Physa) acuta. Ly. truncatula was positively correlated with Ph. acuta. The Neridae Neritina glabrata was positively correlated with five species (Ne. afra Sowerby, 1836, Nr. adansoniana, Nr. rubricata Morelet, 1,858, Melanoide kinshasaensis and Pisidium subtruncatum). The Neridae Ne. afra was positively correlated with two species ( $N r$. adansoniana and Pisidium subtruncatum). The Neridae $N r$. rubricata was positively correlated with three species (Nr. adansoniana, Pa. fusca var. mutans and Pi. subtruncatum). The Neridae $N r$ adansoniana was positively correlated with two species (M. kinshasaensis and Pi. subtruncatum). Pi. subtruncatum was positively correlated with $M$. kinshasaensis. $M$. anomala was positively correlated with two species (Pachymelania fusca var. fusca (Gmelin, 1791) and Pa. fusca var. mutans). Pa. fusca var. fusca was positively correlated with three species (M. angolensis, M. langi and $P a$. aurita. Pa. aurita was positively correlated with two species (M. angolensis and M. langi). Finally, M. langi was positively correlated with M. angolensis (Table 7B). Apart from the significant correlations shown in table 7B, the other correlations were not significant. 
Table 1: Variation in occurrence percentage of the collected snails per family in each quarter.

\begin{tabular}{|c|c|c|c|c|c|c|c|c|c|}
\hline \multirow[b]{2}{*}{ Families } & \multicolumn{8}{|c|}{ Quarters (\%) } & \multirow[b]{2}{*}{ Global (\%) } \\
\hline & I & II & III & IV & $\mathbf{V}$ & VI & VII & VIII & \\
\hline \multicolumn{10}{|c|}{ A. Land snails } \\
\hline Achatinidae & $34(0.84)$ & - & - & $1(0.02)$ & $27(0.66)$ & - & - & $11(0.27)$ & $73(1.79)$ \\
\hline Ferussaciidae & - & - & - & - & $2(0.05)$ & - & - & $6(0.15)$ & $8(0.20)$ \\
\hline Succineidae & $32(0.79)$ & - & $1(0.02)$ & - & $51(1.25)$ & - & - & - & $84(2.06)$ \\
\hline Total A & $66(1.62)$ & - & $1(0.02)$ & $1(0.02)$ & $80(1.97)$ & - & - & 17(0.42) & $165(4.06)$ \\
\hline \multicolumn{10}{|c|}{ B. Freshwater snails } \\
\hline Lymnaeidae & $1(0.02)$ & - & $38(0.93)$ & - & - & - & $211(5.19)$ & - & $250(6.15)$ \\
\hline Neridae & - & $1(0.02)$ & $1(0.02)$ & - & - & $132(3.24)$ & - & - & $134(3.29)$ \\
\hline Physidae & $226(5.56)$ & - & $78(1.92)$ & - & 13(0.32) & - & $233(5.73)$ & - & $550(13.52)$ \\
\hline Planorbidae & - & - & - & - & - & - & - & $6(0.15)$ & $6(0.15)$ \\
\hline Sphaeriidae & - & - & - & - & - & $20(0.49)$ & - & - & $20(0.49)$ \\
\hline Thiaridae & $12(0.29)$ & $1,858(45.67)$ & 163(4.01) & $471(11.58)$ & - & $439(10.79)$ & - & - & $2,943(72.35)$ \\
\hline Total B & $239(5.88)$ & $1,859(45.70)$ & $280(6.88)$ & $471(11.58)$ & $13(0.32)$ & $591(14.53)$ & $444(10.91)$ & $6(0.15)$ & $3,903(95.84)$ \\
\hline Global & $305(7.50)$ & $1,859(45.70)$ & $281(6.91)$ & 472(11.60) & $93(2.29)$ & $591(14.53)$ & $444(10.91)$ & $23(0.57)$ & $4,068(100.00)$ \\
\hline
\end{tabular}

I = Bépanda-Sic-Cacao; II = Cité-Berge; III = Nkomba; IV = Mambanda; V = Mak
Percentages were determined based on the overall total number 4,068 specimens. 
Table 2: Variation in percentage of the species richness per family in each quarter.

\begin{tabular}{|c|c|c|c|c|c|c|c|c|c|}
\hline \multirow[b]{2}{*}{ Families } & \multicolumn{8}{|c|}{ Quarters (\%) } & \multirow[b]{2}{*}{ Global (\%) } \\
\hline & $\mathbf{I}$ & II & III & IV & $\bar{V}$ & VI & VII & VIII & \\
\hline \multicolumn{10}{|l|}{ A. Land snails } \\
\hline Achatinidae & $8(26.7)$ & - & - & $1(3.3)$ & $8(26.7)$ & - & - & $5(16.7)$ & $11(36.7)$ \\
\hline Ferussaciidae & - & - & - & - & $1(3.3)$ & - & - & $1(3.3)$ & $1(3.3)$ \\
\hline Succineidae & $1(3.3)$ & - & $1(3.3)$ & - & $1(3.3)$ & - & - & - & $2(6.7)$ \\
\hline Total A & $9(39.0)$ & - & $1(3.3)$ & $1(3.3)$ & $10(33.3)$ & - & - & $6(20.0)$ & $14(46.7)$ \\
\hline \multicolumn{10}{|c|}{ B. Fresh and brackish water snails } \\
\hline Lymnaeidae & $1(3.3)$ & - & $2(6.7)$ & - & - & - & $2(6.7)$ & - & $2(6.7)$ \\
\hline Neritidae & - & $1(3.3)$ & $1(3.3)$ & - & - & $4(13.3)$ & - & - & $4(13.3)$ \\
\hline Physidae & $1(3.3)$ & - & $1(3.3)$ & - & $1(3.3)$ & - & $1(3.3)$ & - & $1(3.3)$ \\
\hline Planorbidae & - & - & - & - & - & - & - & $1(3.3)$ & $1(3.3)$ \\
\hline Sphaeriidae & - & - & - & - & - & $1(3.3)$ & - & - & $1(3.3)$ \\
\hline Thiaridae & $1(3.3)$ & $2(6.7)$ & $4(13.3)$ & $6(20.0)$ & - & $2(6.7)$ & - & - & $7(23.3)$ \\
\hline Total B & $3(10.0)$ & $3(10.0)$ & $8(26.7)$ & $6(20.0)$ & $1(3.3)$ & $7(23.3)$ & $3(10.0)$ & $1(3.3)$ & $16(53,3)$ \\
\hline Global & $12(40.0)$ & $3(10.0)$ & $9(30.0)$ & $7(23.3)$ & $11(36.7)$ & $7(23.3)$ & $3(10.0)$ & $7(23.3)$ & $30(100.0)$ \\
\hline
\end{tabular}

I = Bépanda-Sic-Cacao; II = Cité-Berge; III = Nkomba; IV = Mambanda; V = Makepé-Missoké; VI = Mbanga-Pongo; VII = Ndogbong; VIII = PK10-Plateau. Percentages were determined based on the overall total number 30 identified species. 
Table 3: Variation in species abundance and percentage of the collected snails per quarter.

\begin{tabular}{|c|c|c|c|c|c|c|c|c|c|}
\hline \multirow[b]{2}{*}{ Family and Species name } & \multicolumn{8}{|c|}{ Quarters (\%) } & \multirow[b]{2}{*}{ Global (\%) } \\
\hline & $\mathrm{I}$ & II & III & IV & $\mathrm{V}$ & VI & VII & VIII & \\
\hline \multicolumn{10}{|l|}{$\begin{array}{l}\text { A. Land snails } \\
\text { Achatinidae }\end{array}$} \\
\hline Achatina achatina (Linnaeus, 1758) & $8(0.2)$ & - & - & - & $2(0.0)$ & - & - & $1(0.0)$ & $11(0.4)$ \\
\hline Ac.(Lissachatina) fulica (Férussac, 1821) & - & - & - & - & $2(0.0)$ & - & - & - & $2(0.0)$ \\
\hline Ac. iredalei Preston, 1910 & $4(0.0)$ & - & - & - & $8(0.2)$ & - & - & $3(0.0)$ & $15(0.4)$ \\
\hline Ac. isotoma (Pfeiffer, 1854) & - & - & - & - & $2(0.0)$ & - & - & - & $2(0.0)$ \\
\hline Ac. raffrayi Jousseaume, 1883 & $4(0.0)$ & - & - & - & $1(0.0)$ & - & - & $3(0.0)$ & $8(0.2)$ \\
\hline Ac. vignoniana Morelet, 1874 & - & - & - & - & - & - & - & $1(0.0)$ & $1(0.0)$ \\
\hline Limicolaria cailliauidi (Pfeiffer, 1850) & $2(0.0)$ & - & - & - & $5(0.1)$ & - & - & $3(0.0)$ & $10(0.3)$ \\
\hline Lissachatina immaculata (Lamarck, 1822) & $8(0.2)$ & - & - & - & $5(0.1)$ & - & - & - & $13(0.3)$ \\
\hline Archachatina marginata var. clenchi Bequaert, 1950 & $3(0.0)$ & - & - & - & - & - & - & - & $3(0.0)$ \\
\hline Ar. marginata var. eduardi Pilsbry, 1909 & $4(0.0)$ & - & - & $1(0.0)$ & $2(0.0)$ & - & - & - & $7(0.2)$ \\
\hline Ar. marginata var. suturalis (Philippes, 1849) & $1(0.0)$ & - & - & - & - & - & - & - & $1(0.0)$ \\
\hline \multicolumn{10}{|l|}{ Ferussaciidae } \\
\hline Caecilioides acicula (Müller, 1774) & - & - & - & - & $2(0.0)$ & - & - & $6(0.2)$ & $8(0.2)$ \\
\hline \multicolumn{10}{|l|}{ Succineidae } \\
\hline Succinea pascali Baudon, 1879 & - & - & - & - & $51(1.3)$ & - & - & - & $51(1.3)$ \\
\hline S. putris (Linnaeus, 1758) & $32(0.8)$ & - & $1(0.0)$ & - & - & - & - & - & $33(0.8)$ \\
\hline Total A & $66(1.6)$ & - & $\mathbf{1 ( 0 . 0 )}$ & $\mathbf{1 ( 0 . 0 )}$ & $80(2.0)$ & - & - & $17(0.4)$ & $165(4.1)$ \\
\hline \multicolumn{10}{|l|}{$\begin{array}{l}\text { B. Freshwater and brackish water snails } \\
\text { Lymnaeidae }\end{array}$} \\
\hline Lymnaea (Galba) truncatula (Müller, 1774) & $1(0.0)$ & - & $35(0.9)$ & - & - & - & $204(5.0)$ & - & $240(5.9)$ \\
\hline Ly. (Radix) natalensis Krauss, 1848 & - & - & $3(0.0)$ & - & - & - & $7(0.2)$ & - & $10(0.3)$ \\
\hline \multicolumn{10}{|l|}{ Neridae } \\
\hline Neritia afra Sowerby, 1836 & - & - & $1(0.0)$ & - & - & $28(0.7)$ & - & - & $29(0.7)$ \\
\hline Neritina adansoniana Recluz, 1841 & - & - & - & - & - & $16(0.4)$ & - & - & $16(0.4)$ \\
\hline
\end{tabular}




\section{Table 3 (continue):}

\begin{tabular}{|c|c|c|c|c|c|c|c|c|c|}
\hline \multirow[b]{2}{*}{ Family and Species name } & \multicolumn{8}{|c|}{ Quarters (\%) } & \multirow[b]{2}{*}{ Global (\%) } \\
\hline & $\overline{\mathrm{I}}$ & II & III & IV & $\mathrm{V}$ & VI & VII & VIII & \\
\hline $\begin{array}{l}\text { B (continue). Freshwater snails } \\
\text { Physidae }\end{array}$ & & & & & & & & & \\
\hline $\begin{array}{l}\text { Physella (Physa) acuta (Draparnaud, 1805) } \\
\text { Planorbidae }\end{array}$ & $226(5.6)$ & - & $78(1.9)$ & - & $13(0.3)$ & - & $233(5.7)$ & - & $550(13,5)$ \\
\hline $\begin{array}{l}\text { Biomphalaria pfeifferi (Krauss, 1848) } \\
\text { Sphaeriidae }\end{array}$ & - & - & - & - & - & - & - & $6(0.2)$ & $6(0.2)$ \\
\hline $\begin{array}{l}\text { Pisidium subtruncatum Malm, } 1855 \\
\text { Thiaridae }\end{array}$ & - & - & - & - & - & $20(0.5)$ & - & - & $20(0.5)$ \\
\hline Melanoïde angolensis Mandahl-Barthm 1974 & - & - & - & $1(0.0)$ & - & - & - & - & $1(0.0)$ \\
\hline M. anomala (Dautzenberg \& Germain, 1914) & - & $1781(43.8)$ & $113(2.8)$ & $321(7.9)$ & - & - & - & - & $2,215(54.5)$ \\
\hline M. kinshasaensis Dupuis \& Putzeys, 1900 & $12(0.3)$ & - & - & - & - & $324(8.0)$ & - & - & $336(8.3)$ \\
\hline M. langi Pilsbry \& Bequaert, 1927 & - & - & $2(0.0)$ & $10(0.3)$ & - & - & - & - & $12(0.3)$ \\
\hline Pachymelania aurita (Muller, 1774) & - & - & - & $24(0.6)$ & - & - & - & - & $24(0.6)$ \\
\hline Pa. fusca var. fusca (Gmelin, 1791) & - & - & $1(0.0)$ & $58(1.4)$ & - & - & - & - & $59(1.5)$ \\
\hline Pa. fusca var. mutans Gould & - & $77(1.9)$ & $47(1.2)$ & $57(1.4)$ & - & $115(2.8)$ & - & - & $296(7.3)$ \\
\hline Total B & $\begin{array}{l}239(5.9) \\
305(75)\end{array}$ & $\begin{array}{l}1,859(45.7) \\
1859(457)\end{array}$ & $280(6.9)$ & $471(11.6)$ & $13(0.3)$ & $\begin{array}{l}591(14.5) \\
591(145)\end{array}$ & $\begin{array}{l}444(10.9) \\
444(109)\end{array}$ & $\begin{array}{l}6(0.2) \\
23(0.6)\end{array}$ & $\begin{array}{l}3,903(95.9) \\
4068(1000)\end{array}$ \\
\hline
\end{tabular}

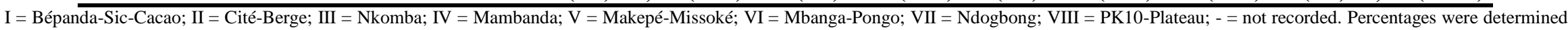
based on the total number 4,068 collected specimens. 

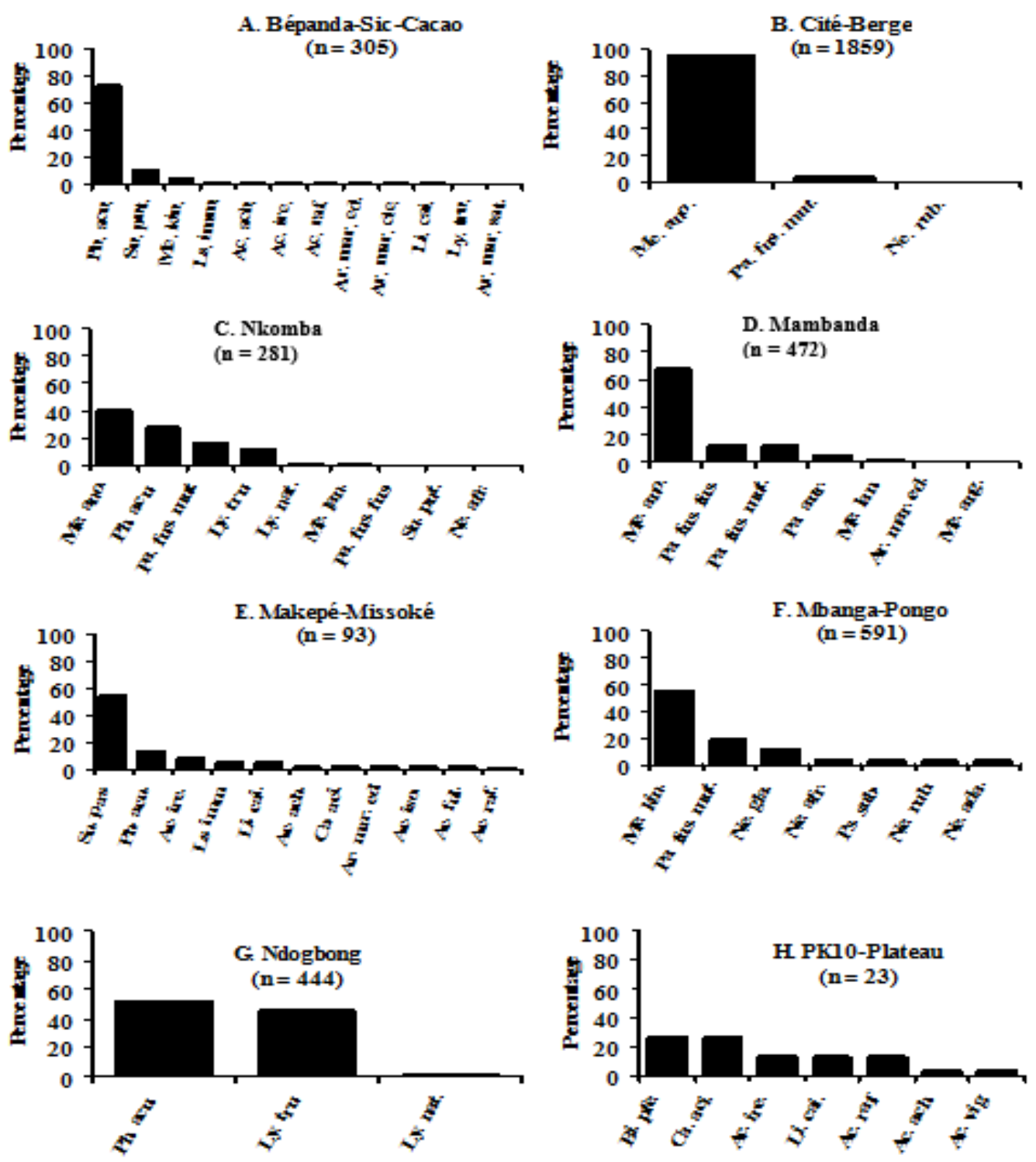

Figure 2: Rank-abundance plotting of the collected frequencies of snails showing species in order of numerical dominance in swampy areas situated in 8 localities of the urban zone of Douala (Littoral-Cameroon).

For each locality percentages of collected snails were calculated from the number of recorded specimens. Ac. ach = Achatina achatina $($ Linnaeus, 1758); Ac. ful. = Achatina fulica $($ Férussac, 1821); Ac. ire. = Achatina iredalei Preston, 1910; Ac. iso = Achatina isotoma (Pfeiffer, 1854); Ac. raf = Achatina raffrayi Jousseaume, 1883; Ac. vig. = Achatina vignoniana Morelet, 1874; Li. cai. = Limicolaria cailliauidi (Pfeiffer, 1850); Ls imm. = Lissachatina immaculata (Lamarck, 1822); Ar. mar. ed. = Archachatina marginata var. eduardi Pilsbry, 1909; Ar. mar. cle. = Archachatina marginata var. clenchi Bequaert, 1950; Ar. mar. sut. = Archachatina marginata var. suturalis (Philippes, 1849); Ce. aci. = Cecilioides acicula $($ Müller, 1774); Ly. tru. = Lymnaea (Galba) truncatula $($ Müller, 1774); Ly. nat. = Lymnaea $($ Radix) natalensis Krauss, 1848; Ne. gla. = Neritina glabrata Sowerby II, 1849; Ne. afr. = Neritina afra Sowerby, 1836; Ne. rub. = Neritina rubricata Morelet, 1858; Ne. ada. $=$ Neritina adansoniana Recluz, 1841; Ph. acu. = Physella $($ Physa $)$ acuta (Draparnaud, 1805); Bi. pfe. = Biomphalaria pfeifferi (Krauss, 1848); Pi. sub. = Pisidium subtruncatum Malm, 1855; Su. put. = Succinea putris (Linnaeus, 1758); Su. pas. = Succinea pascali Baudon, 1879; Me. ang. = Melanoïde angolensis Mandahl-Barthm 1974; Me. ano. = Melanoïde anomala (Dautzenberg \& Germain, 1914); Me. kin. = Melanoïde kinshasaensis Dupuis \& Putzeys, 1900; Me. lan. = Melanoïde langi Pilsbry \& Bequaert, 1927; Pa. fus. mut. = Pachymelania fusca var. mutans Gould; Pa. fus. fus. = Pachymelania fusca var. fusca (Gmelin, 1791); Pa. aur. = Pachymelania aurita (Muller, 1774) 

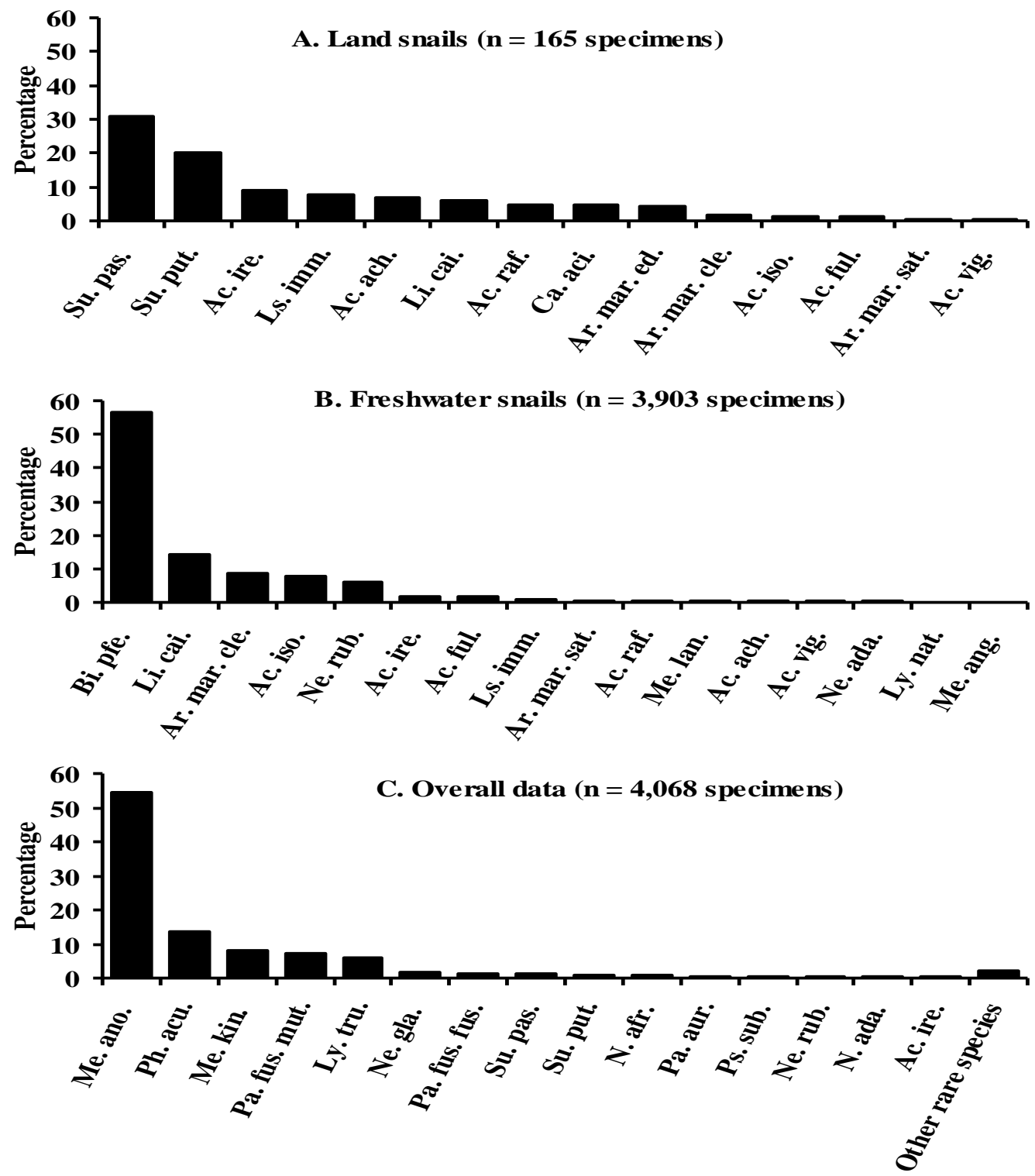

Figure 3: Rank-abundance plotting of the overall frequencies of land snails and freshwater snails showing species in order of numerical dominance in swampy areas of Douala.

Legend to abbreviations is presented in figure 1. Other rare species: group of 15 species (Achatina achatina, Ac. isotoma, Ac. fulica, Ac. raffrayi, Ac. vignoniana, Archachatina marginata clenchi, Ar. marginata eduardi, Ar. marginata saturalis, Caecilioides acicula, Biomphalaria pfeifferi, Limicolaria cailliauidi, Lissachatina immaculata, Lymnaea natalensis, Melanoides angolensis and M. langi). 
Table 4: Matrix of the species richness, diversity, evenness and dominance indexes for each study quarter.

\begin{tabular}{|c|c|c|c|c|c|c|c|c|}
\hline \multirow[b]{2}{*}{ Indexes } & \multicolumn{8}{|c|}{ Quarters } \\
\hline & $\mathbf{I}$ & II & III & IV & $\mathbf{V}$ & VI & VII & VIII \\
\hline \multicolumn{9}{|c|}{ A. Richness indexes } \\
\hline $\begin{array}{l}\text { Sample size } \\
\mathrm{n}(\%)\end{array}$ & $\begin{array}{r}305 \\
(7.5)\end{array}$ & $\begin{array}{l}1,859 \\
(45.7)\end{array}$ & $\begin{array}{r}281 \\
(6.9)\end{array}$ & $\begin{array}{r}472 \\
(11.6)\end{array}$ & $93(2.3)$ & $\begin{array}{r}591 \\
(14.5)\end{array}$ & $\begin{array}{r}444 \\
(10.9)\end{array}$ & $\begin{array}{r}23 \\
(0.6)\end{array}$ \\
\hline $\begin{array}{l}\text { Species } \\
\text { richness S } \\
(\%)\end{array}$ & $\begin{array}{r}12 \\
(40.0)\end{array}$ & $3(10.0)$ & $\begin{array}{r}9 \\
(30.0)\end{array}$ & $\begin{array}{r}7 \\
(23.3)\end{array}$ & $\begin{array}{r}11 \\
(36.7)\end{array}$ & $7(23.3)$ & $3(10.0)$ & $\begin{array}{r}7 \\
(23.3)\end{array}$ \\
\hline $\begin{array}{l}\text { Maximum } \\
\text { abundance }\end{array}$ & 226 & 1,781 & 113 & 321 & 51 & 324 & 233 & 6 \\
\hline Margalef $\mathrm{Mg}$ & 1.923 & 0.266 & 1.419 & 0.975 & 2.206 & 0.940 & 0.328 & 1.914 \\
\hline $\begin{array}{l}\text { Richness } \\
\text { ratio } d=S / n\end{array}$ & 0.039 & 0.002 & 0.032 & 0.015 & 0.118 & 0.012 & 0.007 & 0.304 \\
\hline Chao 1 & 13 & 3 & 11 & 8 & 11 & 7 & 3 & 8 \\
\hline $\begin{array}{l}\text { Sampling } \\
\text { effort }(\%)\end{array}$ & 96.000 & 100.000 & 85.700 & 87.500 & 100.000 & 100.000 & 100.000 & 87.500 \\
\hline \multicolumn{9}{|c|}{ B. Diversity indexes } \\
\hline $\begin{array}{l}\text { Shannon- } \\
\text { Weaver H' }\end{array}$ & 1.063 & 0.177 & 1.424 & 1.034 & 1.591 & 1.364 & 0.761 & 1.771 \\
\hline $\mathrm{H}_{\max }=\ln (\mathrm{S})$ & 2.484 & 1.099 & 2.197 & 1.945 & 2.397 & 1.946 & 1.099 & 1.946 \\
\hline Simpson D & 0.564 & 0.920 & 0.283 & 0.495 & 0.336 & 0.358 & 0.487 & 0.191 \\
\hline $1-\mathrm{D}$ & 0.436 & 0.080 & 0.718 & 0.505 & 0.664 & 0.642 & 0.513 & 0.809 \\
\hline Hill's $1 \mathrm{~N}_{1}$ & 2.897 & 1.194 & 4.156 & 2.813 & 4.910 & 3.911 & 2.141 & 5.875 \\
\hline Hill's $2 \mathrm{~N}_{2}$ & 1.774 & 1.087 & 3.540 & 2.019 & 2.977 & 2.797 & 2.055 & 5.238 \\
\hline $\begin{array}{l}\text { Hill ratio = } \\
\mathrm{N}_{2} / \mathrm{N}_{1}\end{array}$ & 0.612 & 0.911 & 0.852 & 0.718 & 0.606 & 0.715 & 0.960 & 0.892 \\
\hline 1-Hill ratio & 0.388 & 0.089 & 0.148 & 0.282 & 0.394 & 0.285 & 0.040 & 0.108 \\
\hline \multicolumn{9}{|c|}{ C. Evenness index } \\
\hline $\begin{array}{l}\text { Pielou J = } \\
\mathrm{H}^{\prime} / \mathrm{H}_{\max }\end{array}$ & 0.428 & 0.161 & 0.648 & 0.532 & 0.664 & 0.701 & 0.693 & 0.910 \\
\hline \multicolumn{9}{|c|}{ D. Dominance index } \\
\hline $\begin{array}{l}\text { Berger- } \\
\text { Parker I } \mathrm{I}_{\mathrm{BP}}\end{array}$ & 0.741 & 0.958 & 0.402 & 0.680 & 0.548 & 0.548 & 0.525 & 0.261 \\
\hline
\end{tabular}

Table 5: Matrix of the species richness, diversity, evenness and dominance indexes for land snails and freshwater snails.

\begin{tabular}{lrrr}
\hline & Land snails & Freshwater snails & Global \\
\hline A. Richness indexes & & & \\
Sample size n (\%) & $165(4.1)$ & $3,903(95.9)$ & $4,068(100.0)$ \\
Species richness S (\%) & $14(46.7)$ & $16(53.3)$ & $30(100.0)$ \\
Maximum abundance & 51 & 2,215 & 2,215 \\
Margalef Mg & 2.546 & 1.814 & 3.489 \\
Richness ratio d = S/n & 0.085 & 0.004 & 0.007 \\
Chao 1 & 14 & 16 & 31 \\
Sampling effort (\%) & 97.700 & 100.000 & 96.800 \\
& 1314 & &
\end{tabular}




\section{B. Diversity indexes}

Shannon-Weaver H'

$\mathrm{H}_{\max }=\ln (\mathrm{S})$

2.123

1.500

1.695

Simpson D

2.640

2.773

3.402

1-D

0.165

0.360

0.331

Hill's $\mathrm{N}_{1}$

0.835

0.640

0.669

Hill's $\mathrm{N}_{2}$

8.354

4.480

5.445

Hill ratio $=\mathrm{N}_{2} / \mathrm{N}_{1}$

6.050

2.781

3.018

1-Hill ratio

0.724

0.621

0.554

C. Evenness index

0.276

0.379

0.446

Pielou $\mathrm{J}=\mathrm{H}^{\prime} / \mathrm{H}_{\max }$

0.804

0.541

0.498

D. Dominance index

Berger-Parker $I_{\mathrm{BP}}$

0.309

0.568

0.545

Percentages were determined based on the total number of collected specimens or the total number of the recorded species.

Table 6: Values of Akaike Information Criteria (AIC) for the adjustment of species abundance distributions to theoretical models.

\begin{tabular}{lrrr}
\hline Theoretical model & Land snails & Freshwater snails & Global \\
\hline Broken-stick (McArthur) & 63.929 & 3077.530 & 5304.640 \\
Loglinear (Motomura) & 64.408 & 692.940 & 1432.730 \\
Lognormal (Preston) & $61.052 *$ & $240.590 *$ & $313.810 *$ \\
Zipf & 68.143 & 342.150 & 346.090 \\
Zipf-Mandelbroot & 65.729 & 307.840 & 325.060 \\
\hline * = the best fitted theoretical species abundance distribution model
\end{tabular}

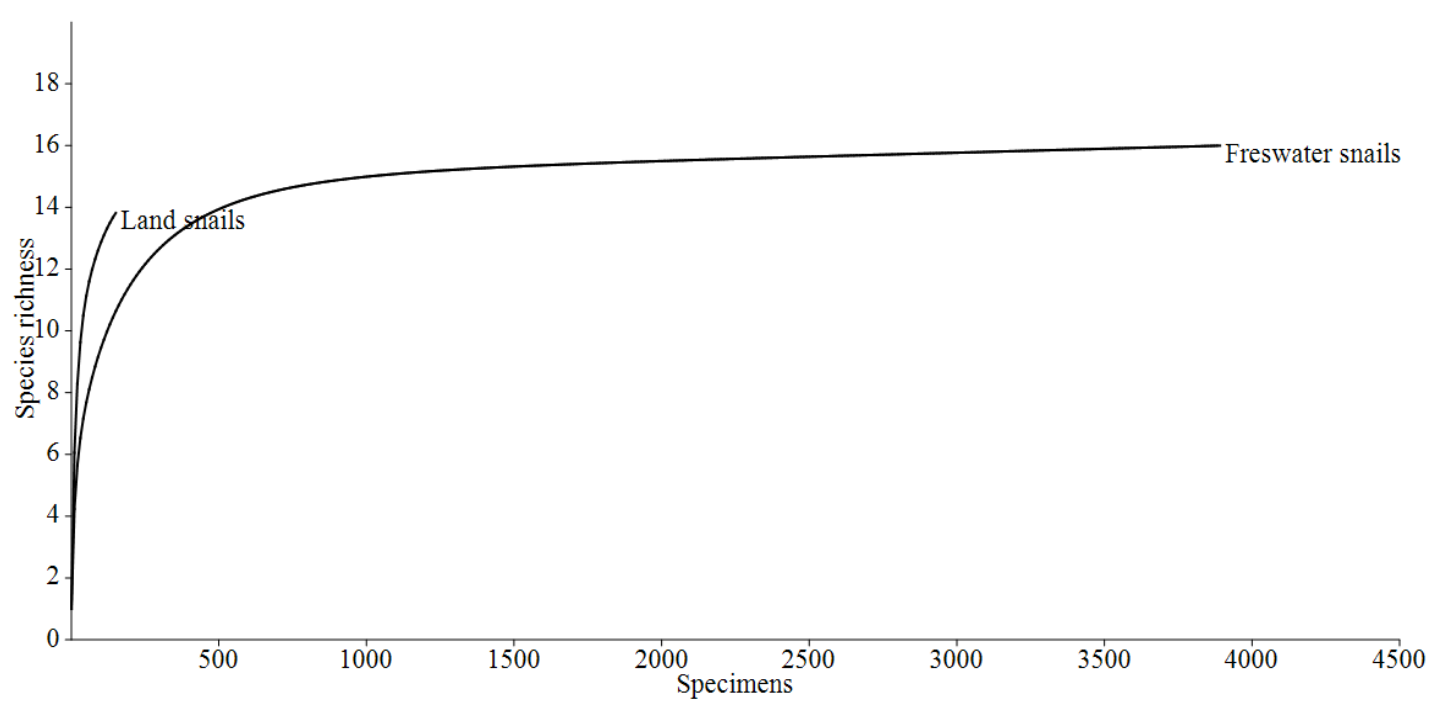

Figure 4: Species rarefaction curve for the land snail and the freshwater snail communities. 
Table 7: Significant values of the Kendall's tau $\tau$ correlation coefficient between ant species.

\begin{tabular}{|c|c|c|c|c|c|}
\hline \multirow[b]{2}{*}{ Species } & \multicolumn{2}{|c|}{ A. Land snails } & \multicolumn{3}{|l|}{ B. Freshwater snails } \\
\hline & $\tau$ & $\begin{array}{r}\text { p- } \\
\text { value }\end{array}$ & Species & $\tau$ & p-value \\
\hline Achatina achatina & & & Neritina glabrata & & \\
\hline Ac. iredalei & 0.889 & $0.002 *$ & $\begin{array}{c}\text { Melanoïde } \\
\text { kinshasaensis }\end{array}$ & 0.734 & $0.011 *$ \\
\hline Ac. raffrayi & 0.889 & $0.002 *$ & Neritia afra & 0.734 & $0.011 *$ \\
\hline Archachatina marginata eduardi & 0.667 & $0.021 *$ & Nr. adansoniana & 1.000 & $0.001 *$ \\
\hline Ar. marginata clenchi & 0.624 & $0.031 *$ & Nr. rubricata & 0.734 & $0.011 *$ \\
\hline Ar. marginata saturalis & 0.624 & $0.031 *$ & Psidium subtruncatum & 1.000 & $0.001 *$ \\
\hline Limicolaria cailliauidi & 0.778 & $0.007 *$ & Nr. rubricata & & \\
\hline Lissachatina immaculata & 0.850 & $0.003 *$ & Nr. adansoniana & 0.734 & $0.011 *$ \\
\hline Ac. iredalei & & & $\begin{array}{l}\text { Pachymelania fusca } \\
\text { mutans }\end{array}$ & 0.769 & $0.008 *$ \\
\hline Ac. fulica & 0.624 & $0.031 *$ & Ps. subtruncatum & 0.734 & $0.011 *$ \\
\hline Ac. isotoma & 0.624 & $0.031 *$ & Nr. adansoniana & & \\
\hline Ac. raffrayi & 0.778 & $0.007 *$ & M. kinshasaensis & 0.734 & $0.011 *$ \\
\hline Caecilioides acicula & 0.588 & $0.042 *$ & Ps. subtruncatum & 1.000 & $0.001 *$ \\
\hline Li. cailliauidi & 0.889 & $0.002 *$ & Ps. subtruncatum & & \\
\hline Ls. immaculata & 0.719 & $0.013 *$ & M. kinshasaensis & 0.734 & $0.011 *$ \\
\hline Succinea pascali & 0.624 & $0.031 *$ & Ar. marginata eduardi & & \\
\hline Ac. fulica & & & Ar. marginata clenchi & 0.624 & $0.031 *$ \\
\hline S. pascali & 1.000 & $0.001 *$ & Ar. marginata saturalis & 0.624 & $0.031 *$ \\
\hline Ac. isotoma & & & Ar. marginata clenchi & & \\
\hline Ac. fulica & 1.000 & $0.001 *$ & Ar. marginata saturalis & 1.000 & $0.001 *$ \\
\hline S. pascali & 1.000 & $0.001 *$ & Succinea putris & 0.734 & $0.011 *$ \\
\hline Ac. raffrayi & & & Ar. marginata saturalis & & \\
\hline Ar. marginata clenchi & 0.624 & $0.031 *$ & S. putris & 0.734 & $0.011 *$ \\
\hline Ar. marginata saturalis & 0.624 & $0.031 *$ & Li. cailliauidi & & \\
\hline C. acicula & 0.588 & $0.042 *$ & Ac. isotoma & 0.624 & $0.031 *$ \\
\hline Ac. vignoniana & & & Ac. fulica & 0.624 & $0.031 *$ \\
\hline C. acicula & 0.734 & $0.011 *$ & Ac. raffrayi & 0.667 & $0.021 *$ \\
\hline Lymnaea natalensis & & & C. acicula & 0.719 & $0.013 *$ \\
\hline Ly. truncatula & 0.850 & $0.003 *$ & S. pascali & 0.624 & $0.031 *$ \\
\hline Physa acuta & 0.650 & $0.005 *$ & Ls. immaculata & & \\
\hline Ly. truncatula & & & Ac. raffrayi & 0.719 & $0.013 *$ \\
\hline Ph. acuta & 0.804 & $0.024 *$ & Ar. marginata eduardi & 0.850 & $0.003 *$ \\
\hline Neritia afra & & & Ar. marginata clenchi & 0.734 & $0.011 *$ \\
\hline Neritina adansoniana & 0.734 & $0.011 *$ & Ar. marginata saturalis & 0.734 & $0.011 *$ \\
\hline Psidium subtruncatum & 0.734 & $0.011 *$ & Li. cailliauidi & 0.588 & $0.042 *$ \\
\hline M. anomala & & & Pa. aurita & & \\
\hline Pa. fusca fusca & 0.588 & $0.042 *$ & M. angolensis & 1.000 & $0.001 *$ \\
\hline Pa. fusca mutans & 0.603 & $0.037 *$ & M. langi & 0.734 & $0.011 *$ \\
\hline Pa. fusca fusca & & & M. langi & & \\
\hline M. angolensis & 0.734 & $0.011 *$ & M. angolensis & 0.734 & $0.011 *$ \\
\hline M. langi & 1.000 & $0.001 *$ & & & \\
\hline Pa. aurita & 0.734 & $0.011 *$ & & & \\
\hline
\end{tabular}




\section{DISCUSSION}

\section{Species richness, abundance and dominance}

The present study is the first step in evaluating the community structure of snails in urban areas of the coastal littoral-zone of Douala (Cameroon). A total of 4,068 specimens collected in eight quarters of Douala city (165 land snails and 3,903 freshwater snails) belonged to nine families: three families of land snails (Achatinidae, Ferussaciidae and Succinidae) and six families of freshwater snail (Lymnaeidae, Nereidae, Physidae, Planorbidae, Sphaeriidae and Thiaridae), 14 genera divided into six genera of land snails (Achatina, Limicolaria, Lissachatina, Archachatina, Caecilioides and Succinea) and eight genera of freshwater snails (Lymnaea, Neritia, Neritina, Physa, Biomphalaria, Pisidium, Melanoides and Pachymelania) and 30 species divided into 14 species of land snails and 16 species of freshwater snails. Then the anthropized environments of Douala presented very low snail-species richness compared to the situation noted in natural environments. As example, recent reports point out 102 land snail species in the Nyungwe Forest National Park of south-western Rwanda which is the richest forest known in Africa (Boxnick et al., 2015) and 42 land snail species in the Palestinian Territories of the West Bank (Amr et al., 2018). This is also the case when compared with the situation reported in other perturbed environments all over the world: 24 species in a threatened limestone district near Istanbul, Turkey (Örstan et al., 2005). In the Douala urban areas, the species of Achatinidae are rarely represented in four populous quarters (Bépanda, Mambanda, Maképé-Missoké and PK10-Plateau) where market gardening is practiced along streams and around marshes while they are absent in other localities. It is obvious that in the above four infested localities, in spite of the low abundance of Achatinidae, they damage cultivated vegetables, as is the case elsewhere where they are established. Regarding aquatic snails, our results are clearly close to those recorded in five provinces of northwestern Angola where nine genera have been identified using morphological characteristics: Biomphalaria, Bulinus, Gyraulus, Lanistes, Lentorbis, Lymnaea, Melanoides, Physa and Succinea (Allan et al., 2017). Significant for parasitic disease transmission in the coastal city of Douala, was the discovery of the Lymneidae species Lymnaea (Galba) truncatula and Ly. (Radix) natalensis which are obligate intermediate host of the giant liver fluke Fasciola gigantica Cobbold, 1855, which causes bovine distomatosis in herbivores, and possibly also of Fasciola hepatica Linnaeus, 1758 for human distomatosis (Mbuh and Mbwaye, 2005; JeanRichard et al., 2014; Aleixo et al., 2015; Isah, 2019). Moreover, the presence of the Planorbidae species Biomphalaria pfeifferi only in the locality of PK10-Plateau transforms this locality into a risk environment for bilharzia (Gryseels, 1985; De Clercq, 1987; Dreyfuss and Rondelaud, 2011; Bridger et al., 2018; Chibwana et al., 2020). According to the reports, the strongly anthropized sites are clearly less rich than the natural sites or sites undergoing regeneration process and anthropogenic disturbance plays a key role in shaping species diversity and community structure of land snail fauna (Douglas et al., 2013). The low species diversity of land snails and freshwater snails recorded in anthropized areas of the Littoralzone of Douala (Cameroon) reflects either the low level of maturity (unsaturation) of the snail community, the degradation of the environmental quality or the negative effect of 
the presence of both native and invasive species. The land snails Achatinidae [Achatina achatina and Ac. (Lissachatina) fulica] have invaded several regions of the world where they are causing damage to agriculture (Ismail et al., 2003). The low abundance and the low diversity of land snails in our study can be explain by the overcollection of large sized adults from the wild by city residents for consumption or for sale in local markets.

The freshwater snails Physidae Physella (Physa) acuta and Planorbidae Biomphalaria pfeifferi are known to be medically important for humans and livestock health since they are obligate intermediate host of distomatosis and schistosomiasis agents, respectively (Dreyfuss and Rondelaud, 2011; Andreazzi et al., 2017; Bridger et al., 2018; d'Ovidio et al., 2019; Chibwana et al., 2020). The low species diversity is associated with low abundance in native snails, resulting in the weak exploitation of resources. Moreover, the exploitation of both food and nest sites seemed to be mostly achieved by these invasive species. The highly abundance level of the invasive Achatinidae species in the introduced range is well known. The striking result is the high occurrence level of these pest species in the native range. They are generally considered as among the most ecologically destructive in cultivated areas where they have been introduced (Ismail et al., 2003). The spreading out of native snails in the coastal zone of Cameroon is certainly be explained by the changing conditions in the environment (deforestation, enlargement of cultivated areas, and extension of the city) as is the case in India (Rekha Sarma et al., 2015). Since in undisturbed areas, snail species are organized in structured communities and as long as there is no disturbance, potential pest snails are regulated by competition or predation and can not reach high population densities, our investigations confirm that in the Littoral-zone of Cameroon, snail communities are highly perturbed by invasive species. In the near future, if nothing is done, populations of aquatic molluscs of medical importance will expand and lead to the growth of cases of schistosomiasis or bilharzia infections. In fact, the planorbid species recorded in Douala appears in the list of five species (Biomphalaria glabrata, Bi. straminea, Bi. tenagophila, Bi. pfeifferi and Indoplanorbis exustus) known to be transported by man through the aquatic plant trade and establishing viable populations in new habitats where they spread easily and they can be considered as pests because of their role in the transmission of parasites to humans or domestic animals (Pointier et al., 2005). According to the same authors the neotropical species Bi. glabrata, Bi. straminea and Bi. tenagophila have invaded another continent sometimes creating new transmission foci. The African species $B i$. pfeifferi and the Indian species I. exustus are able to expand their distribution area with long distance dispersal.

\section{Community structure model}

Based on the AIC values, snail species from land, streams and swamps belonged to the same lognormal nomocenose model. The lognormal niche partitioning model is reported fitting the abundance distribution of several invertebrate communities including snails (Béguinot, 2018; Kunakh and Kovalenko, 2019) and Insects inhabiting climax and paraclimax environments (Errouissi et al., 2004; Komonen and Elo, 2017; YetchomFondjo et al., 2020). This model therefore seems to characterize the stands of open or less disturbed environments where there is strong competition between species for the 
exploitation of available resources. Human activities in general resulting in urbanization, growing cities, extensive deforestation and the extension of cultivated areas have been reported to modify land cover, to reduce the area of natural habitats, to affect ecosystem functioning and to contribute to the loss of biodiversity (McDonald et al., 2013). Our results therefore show that in the urban area of the littoral region of Cameroon, land snail and freshwater snail communities have developed a complex network of information quite close to that of evolved environments.

\section{Resources availability as a predictor of species abundances}

Despite the fact that, land snail invasive species that destroy crops and freshwater snail species of medical importance belong to the category of rare species, their populations could increase in the near future as a result of intense anthropic activity and growing insalubrity which eliminates native competitive species. Despite the drop in the prevalence of schistosomiasis in the neighbouring endemic locality of Njombé-Penja (Ndzenou et al., 2020), this infectious disease may spread in the near future to the city of Douala, especially if the locality at risk is visited by infected people, who defecate, or urinate in streams or swamps as is the habit of populations who live in populous areas of the city and where environmental cleanliness is not respected

In conclusion, the terrestrial malacofauna of the urban area of Douala is dominated by the Succinidae family (50.9\%) followed by Achatinidae (44.2\%) and finally by Ferussacidae (4.8\%) while the aquatic malacofauna is largely dominated by the Thiaridae family (75.4\%) followed by Physidae (14.2\%), Lymnaeidae (6.4\%), Neridae $(3.4 \%)$, Sphaeriidae $(0.5 \%)$ and finally by Planorbidae (0.2\%). Pk10-Plateau quarter is due to the presence of Planorbidae Biomphalaria pfeifferi, an area at risk for the production of schistosomiasis infectious agent while three quarters (Bépanda-Sic-Cacao, Nkomba and Ndogbong) are due to the presence of Lymnaea (Lymneae truncatula and Ly. natalensis), localities at risk for the production of fascioliasis infectious agent. A significant number of resources are potentially exploitable by invasive snails such as the Achatinidae land snails [Ac. achatina and Ac. fulica] and the medically important Planorbidae Biomphalaria pfeifferi in the infested Littoral-zone of Cameroon. These species could acquire other resources, as most as they are exploited by native snail species. In this infested zone, all the conditions combine to soar. In due course, once the invader would completely monopolize available resources and saturate the area, it would not allow native snails the niche opportunities to re-establish themselves. The consequences of loosing native snails, which may well interact with the diverse and endemic flora, will be of extreme concern.

\section{COMPETING INTERESTS}

The authors declare that they have no competing interests.

\section{AUTHORS' CONTRIBUTIONS}

ELK and MK conceived and planned the field investigations and identification of specimens to species level. MK carried out statistical data analysis. The other authors participated in the field mollusc collection sessions, in the sorting of the collected specimens in morphospecies and they contributed to the writing of the final manuscript. 


\section{ACKNOWLEDGEMENTS}

Authors are grateful to the members of the Biological Control Unit (University of Douala), for the field technical assistance. We would like to thank the inhabitants of Douala town and of the suburbs zones for having warmly welcomed us in their respective homes and/or in their cultivated plots.

\section{REFERENCES}

Adang LK, Kela SL, Kashere MB. 2015. Fascioliasis in cattle slaughtered at Gombe abattoir, Nigeria. Int. J. Biol. Chem. Sci., 9(2): 783-792. DOI: http://dx.doi.org/10.4314/ijbcs.v9i2.18.

Adeyeye SAO, Bolaji OT, Abegunde TA, Adesina TO. 2020. Processing and utilization of snail meat in alleviating protein malnutrition in Africa: a review. Nutr. Food Sci., 50(6): 1085-1097. DOI: 10.1108/NFS-08-2019-0261.

Aleixo MA, Freitas DF, Dutra LH, Malone J, Martin IVF, Molento MB. 2015. Fasciola hepatica: epidemiology, perspectives in the diagnostic and the use of geoprocessing systems for prevalence studies. Semin., Ciênc. Agrár., 36(3): 1451-1465. DOI: $10.5433 / 1679$ 0359.2015v36n3p1451

Allan F, Sousa-Figueiredo JC, Emery AM, Paulo R, Mirante C, Sebastião A, Brito M, Rollinson D. 2017. Mapping freshwater snails in north-western Angola: distribution, identity and molecular diversity of medically important taxa. Parasit. Vectors, 10:460. DOI: 10.1186/s13071-017-2395-y

Amr ZS, Najajreh MN, Zawahrah M, Neubert E, Handal EN, Baker MA, Qumsiyeh MB. 2018. Diversity and ecology of the land snails of the Palestinian Territories of the West Bank. Zool. Ecol., 28(1): 25-
35.

DOI:

10.1080/21658005.2017.1419107

Andreazzi MA, Gasparotto F, de Souza Paccola EA, da Silva CN, Rodrigues AFC, Perez Lizama MA. 2017. Giant african snail, Achatina fulica (Férussac, 1821): an environmental and public health problem in the northwestern of Paraná State, Brazil. Acta Sci. Biol. Sci., 39(3): 301-307. DOI: 10.4025/actascibiolsci.v39i3.35569

Béguinot J. 2018. Analysing the Role of Environmental Stresses on Species Richness and the Process of Hierarchical Structuring of Species Abundances in Marine Gastropods communities at Suva (Fiji Islands). Int. J. Environ., 8(3): 200233. DOI: $10.9734 /$ IJECC/2018/44913

Bouthir FZ, Chafik A, Benbrahim, Souabi S, El Merdhy H, Messoudi A, Sifeddine M. 2004. Quality of Wilaya du grand Casablanca coastal waters (Morocco, Atlantic Ocean): the mussel Mytilus galloprovincialisas an indicator of metal contamination. Mar. Life, 14(1-2): 59-70.

Boxnick A, Apio A, Wronski T, Hausdorf B. 2015. Diversity patterns of the terrestrial snail fauna of Nyungwe Forest National Park (Rwanda), a Pleistocene refugium in the heart of Africa. Biol. J. Linn. Soc., 114(2): $\quad 363-375 . \quad$ DOI: 10.1111/bij. 12418

Bridger JM, Brindley PJ, Knight M. 2018. The snail Biomphalaria glabrata as a model to interrogate the molecular basis of complex human diseases. PLOS Negl. Trop. Dis., 12(8): e0006552. DOI: 10.1371/journal.pntd.0006552

Cheng C-C. 2004. Statistical approaches on discriminating spatial variation of species diversity. Bot. Bull. Acad. Sinica, 45: 339-346.

DOI: 10.7016/BBAS.200410.0339 
Chibwana FD, Tumwebaze I, Mahulu A, Sands AF, Albrecht C. 2020. Assessing the diversity and distribution of potential intermediate hosts snails for urogenital schistosomiasis: Bulinus spp. (Gastropoda: Planorbidae) of Lake Victoria. Parasit. Vectors, 13(1): 418, PMID: $\quad 32795373$ : PMCID: PMC7427762

Clavel I. 2015. Les Mollusques. L'embranchement aux 130000 espèces. Villeneuve le roi, Plongée.

Climate-Data.org. 2021. Douala Climat (Cameroun). Available online at https://fr.climate-

data.org/afrique/cameroun/littoral/douala -890444/ (Assessed on 20 January 2021)

Colley DG, Bustinduy AL, Secor WE, King CH. 2014. Human schistosomiasis. Lancet, 383(9936): 2253-2264. DOI: 10.1016/S0140-6736(13)61949-2.

Cucherat X, Demuynck S. 2006. Catalogue annoté des Gastéropodes terrestres (Mollusca, Gastropoda) de la région Nord-Pas-de-Calais. MalaCo, 2: 40-91.

Daget J. 2003. Les Mollusques terrestres et fluviatiles du mont Nimba. In Le Peuplement Animal du Mont Nimba (Guinée, Côte d'Ivoire, Liberia), Lamotte M, Roy R (eds). Mémoires du Muséum national d'Histoire naturelle, $\mathrm{T}$. 190: Paris; 183-209.

Dawet A, Yakubu DP, Longmut R, Benjamin CB, Daburum YH, Nannim N. 2012. Prevalence and intensity of Schistosoma haematobium among residents of Gwong and Kabong in Jos North Local Government Area, Plateau State, Nigeria. Int. J. Biol. Chem. Sci., 6(4): 1557-1565. DOI:

http://dx.doi.org/10.4314/ijbcs.v6i4.15

De Clercq D. 1987. La situation malacologique à Kinshasa et description d'un foyer autochtone de schistosomiase à Schistosoma intercalatum. Ann. Soc. Belg. Med. Trop., 67: 345-352.

Douglas DD, Brown DR, Pederson N. 2013. Land snail diversity can reflect degrees of anthropogenic disturbance. Ecosphere, 4(2): 28. DOI: 10.1890/ES12-00361.1

d'Ovidio D, Nermut J, Adami C, Santoro M. 2019. Occurrence of Rhabditid Nematodes in the Pet Giant African Land Snails (Achatina fulica). Front. Vet. Sci., $\quad$ 6: $\quad 88 . \quad$ DOI: 10.3389/fvets. 2019.00088

Dreyfuss G, Rondelaud D. 2011. Les Mollusques dans la transmission des helminthiases humaines et vétérinaires. Bull. Acad. Vet. Fr., 164(1): 13-20. DOI: $10.4267 / 2042 / 48064$

Errouissi F, Jay-Robert P, Lumaret J-P, Piau A. 2004. Composition and Structure of Dung Beetle (Coleoptera: Aphodiidae, Geotrupidae, Scarabaeidae) Assemblages in Mountain Grasslands of the Southern Alps. Ann. Entomol. Soc. Am., 97(4): 701-709. DOI: $\quad$ D. $\quad$ D.1603/00138746(2004)097[0701:casodb]2.0.co;2

Galli C. 2013. WMSDB - Worldwide Mollusc Species Data Base by Bagni Liggia Genova - Italy. Available online at https://www.bagniliggia.it/WMSD/WMS Ddownload.htm (Accessed on 20 January 2021).

Gerlach J, Barker GM, Bick CS, Bouchet P, Brodie G, Christensen CC, Collins T, Coote T, Cowie RH, Fiedler GC, Griffiths OL, Florens FBV, Hayes KA, Kim J, Meyer J-Y, Meyer III WM, Richling I, Slapcinsky JD, Winsor L, Yeung NW. 2021. Negative impacts of invasive predators used as biological control agents against the pest snail Lissachatina fulica: the snail Euglandina rosea and the flatworm Platydemus 
manokwari. Biol. Invasions, 23: $997-$ 1031. DOI:

https://doi.org/10.1007/s10530-02002436-w

Gryseels B. 1985. La répartition de Biomphalaria et la transmission de Schistosoma dans la plaine de la Ruzizi, Burundi : étude préliminaire. Ann. Soc. Belg. Med. Trop., 65: 49-58. http://lib.itg.be/open/asbmt/1985/1985as bm0049.pdf

Hammer $\varnothing$, Harper DAT, Ryan PD. 2001. PAST: Paleontological Statistics Software Package for Education and Data Analysis. Palaeontol. Electron., 4(1): $\quad 1-9 . \quad$ DOI: https://doi.org/10.12691/aees-3-6-5

Heikal HM. 2015. Biological aspects and population dynamics of three terrestrial snails infesting fruit trees in Egypt. Int. J. Adv. Res. Biol. Sci., 2(1): 169-180.

Isah UM. 2019. Studies on the prevalence of fascioliasis among ruminant animals in northern Bauchi state, north-eastern Nigeria. Parasite Epidemiol. Control., 5: e00090.

DOI: 10.1016/j.parepi.2019.e00090

Ismail AS, El-Massry SA, Khattab MM, Hassan AS. 2003. Daily activity and damage caused by Eobania vermiculata Müller (Gastropoda: Helicidae) in citrus orchards. Egypt. J. Appl. Sci., 18: 1-6.

Jean-Richard V, Crump L, Abicho AA, Naré NB, Greter H, Hattendorf J, Schelling E, Zinsstag J. 2014. Prevalence of Fasciola gigantica infection in slaughtered animals in south-eastern Lake Chad area in relation to husbandry practices and seasonal water levels. BMC Vet. Res., 10: 81. DOI: https://doi.org/10.1186/17466148-10-81

Johnson JB, Omland KS. 2004. Model selection in ecology and evolution.
Trends Ecol. Evol., 19(2): 101-108. DOI: https://doi.org/10.1016/j.tree.2003.10.01 3

Kant R, Diarra SS. 2016. Feeding Strategies of Giant African Snail Achatina fulica on Papaya in Samoa. Acta Hortic., 1128: 229-236.

DOI:

10.17660/ActaHortic.2016.1128.35.

Kikvidze Z, Oshawa M. 2002. Measuring the number of co-dominants in ecological communities. Ecol. Res., 17: 519-525. DOI: https://doi.org/10.1046/j.14401703.2002.00508.x

Komonen A, Elo M. 2017. Ecological response hides behind the species abundance distribution: Community response to low-intensity disturbance in managed grasslands. Ecol. Evol., 7: 8558-8566.

DOI: https://doi.org/10.1002/ece3.3395

Kottek M, Grieser J, Beck C, Rudolf B, Rubel F. 2006. World Map of the KöppenGeiger Climate Classification Updated. Meteorol. Z., 15(3): 259-263. DOI: https://doi.org/10.1127/0941-

2948/2006/0130

Kunakh O, Kovalenko D. 2019. Fitting Competing Models of the Population Abundance Distribution: Land Snails from Nikopol Manganese Ore basin Technosols. Ekol. Bratisl., 38(4): 367381. DOI: https://doi.org/10.2478/eko2019-0027

Mbuh JV, Mbwaye J. 2005. Serological changes in goats experimentally infected with Fasciola gigantica in Buea subdivision of S.W.P. Cameroon. Vet. Parasitol., 131(3-4): 255-259. DOI: https://doi.org/10.1016/j.vetpar.2005.05. 013.

McDonald RI, Marcotullio PJ, Güneralp B. 2013. Urbanization and Global Trends in Biodiversity and Ecosystem Services. In 
Urbanization, Biodiversity and Ecosystem Services: Challenges and Opportunities. A Global Assessment. A Part of the Cities and Biodiversity Outlook Project, Elmqvist T, Fragkias M, Goodness J, Güneralp B, Marcotullio P J, McDonald RI, Parnell S, Schewenius M, Sendstad M, Seto KC, Wilkinson C (eds). The Netherlands: Springer Open, Springer, Dordrecht, Heidelberg, New York, London; 31-52. DOI: https://doi.org/10.1007/978-94-0077087-4

Memel J-D, Komara M, Karamoko M, Kouamé KE, Otchoumou A. 2017. Morphometric Identification of Two Species of Achatinidae: Achatina Achatina Linné, 1758 and Archachatina ventricosa Gould, 1850. Int. J. Eng. Sci., 6(12): 5-10.

DOI:

https://doi.org/10.9790/1813-

0612040510

MolluscaBase eds. 2021. MolluscaBase. Accessed http://www.molluscabase.org on 202107-07. DOI: 10.14284/448.

Mouthon J. 1982. Les mollusques dulcicoles données biologiques et écologies - clés de détermination des principaux genres de bivalves et de gastéropodes de France. Bull. Fr. Piscic., Hors Serie: 1-27. DOI: https://doi.org/10.1051/kmae:1982001

Ntonifor HN, Ajayi JA. 2007. Studies on the ecology and distribution of some medically important freshwater snail species in Bauchi State, Nigeria. Int. J. Biol. Chem. Sci., 1(2): 121-127. DOI: 10.4314/ijbcs.v1i2.39681

Nzenou CGD, Tientche B, Asaah S, Wandji JMT, Kenne M. 2020. An Update on Schistosomiasis: Prevalence, Intensity of Infection and Risk Factors among School-Aged Children in Njombe,
Littoral Region, Cameroon. Int. J. Trop. Dis. Health,

41(3): 63-76. DOI: https://doi.org/10.9734/IJTDH/2020/v41i 330264

Örstan A, Pearce TA, Welter-Schultes F. 2005. Land snail diversity in a threatened limestone district near Istanbul, Turkey. Anim. Biodivers. Conserv., 28(2): 181188.

Pointier JP, David P, Jarne P. 2005. Biological invasions: the case of planorbid snails. $J$. Helminthol., 79: 249-256. DOI: https://doi.org/10.1079/JOH2005292

R-Core Team. 2018. R: A Language and Environment for Statistical Computing. R Foundation for Statistical Computing, Vienna. Available online at http://www.R-project.org/ (Accessed on 10 November 2020).

Rekha Sarma R, Munsi M, Neelavara Ananthram A. 2015. Effect of Climate Change on Invasion Risk of Giant African Snail (Achatina fulica Férussac, 1821: Achatinidae) in India. PLoS ONE, 10(11): e0143724. DOI: https://doi.org/10.1371/journal.pone.014 3724

Saotoing P, Djonyang R, Dereng DD, Njan Nlôga A-M. 2016. Epidemiological investigation of urinary and intestinal parasites among primary schoolchildren in the district Maga, Far North Cameroon. Int. J. Biol. Chem. Sci., 10(1): 344-354.

DOI: http://dx.doi.org/10.4314/ijbcs.v10i1.26

Shea K, Chesson P. 2002. Community ecology theory as a framework for biological invasions. Trends Ecol. Evol., 17(4): $\quad 170-176 . \quad$ DOI: https://doi.org/10.1016/S01695347(02)02495-3 
Tonga C, Ngo Bayoi C, Tchanga FC, Yengue JF, Wepnje GB, Nyabeyeu Nyabeyeu H, Kangam L, Koudjip Nono L, Akono Ntonga P, Lehman LG. 2019. Schistosomiasis among pregnant women in Njombe-Penja health district, Cameroon. J. Infect. Dev. Ctries., 13(12): 1150-1158. DOI: 10.3855/jidc. 11767.

Vrignaud S. 2011. Clé de détermination des familles de mollusques continentaux d'Auvergne. Bull. Moll. Auvergne, 9: 115.

Welter-Schultes F, Audibert C, Bertrand A. 2011. Liste des mollusques terrestres et dulcicoles de France continentale (excl. hydrobioïdes). Folia conchyliol., 12: 44.
Yapi GY, Toure M, Sarr MD, Abo N, Diabaté S. 2017. The impact of irrigated rice on the transmission of schistosomiasis and geohelminthiasis in Niakaramandougou, Côted'Ivoire. Int. J. Biol. Chem. Sci., 11(4): $\quad$ 1400-1412. DOI: http://dx.doi.org/10.4314/ijbcs.v11i4.1

Yetchom-Fondjo JA, Kekeunou S, Kenne M, Missoup AD, Sheng-Quan X. 2020. Diversity, abundance and distribution of grasshopper species (Orthoptera: Acrididea) in three different types of vegetation with different levels of anthropogenic disturbances in the Littoral Region of Cameroon. J. Insect Biodivers., $\quad$ 14(1): $16-33$. https://doi.org/10.12976/jib/2020.14.1.3 